Portland State University

PDXScholar

$5-19-1988$

\title{
Cheever's Signs : A Semiotic Approach to Thirteen Stories by John Cheever
}

\section{Laurent Ditmann}

Portland State University

Follow this and additional works at: https://pdxscholar.library.pdx.edu/open_access_etds

Part of the Literature in English, North America Commons Let us know how access to this document benefits you.

Recommended Citation

Ditmann, Laurent, "Cheever's Signs : A Semiotic Approach to Thirteen Stories by John Cheever" (1988). Dissertations and Theses. Paper 3741.

https://doi.org/10.15760/etd.5625

This Thesis is brought to you for free and open access. It has been accepted for inclusion in Dissertations and Theses by an authorized administrator of PDXScholar. Please contact us if we can make this document more accessible: pdxscholar@pdx.edu. 
AN ABSTRACT OF THE THESIS OF Laurent Ditmann for the Master of Arts in English presented May 19, 1988

Title: Cheever's Signs: A Semiotic Approach To Thirteen Stories by John Cheever.

APPROVED BY THE MEMBERS OF THE THESIS COMMITTEE:

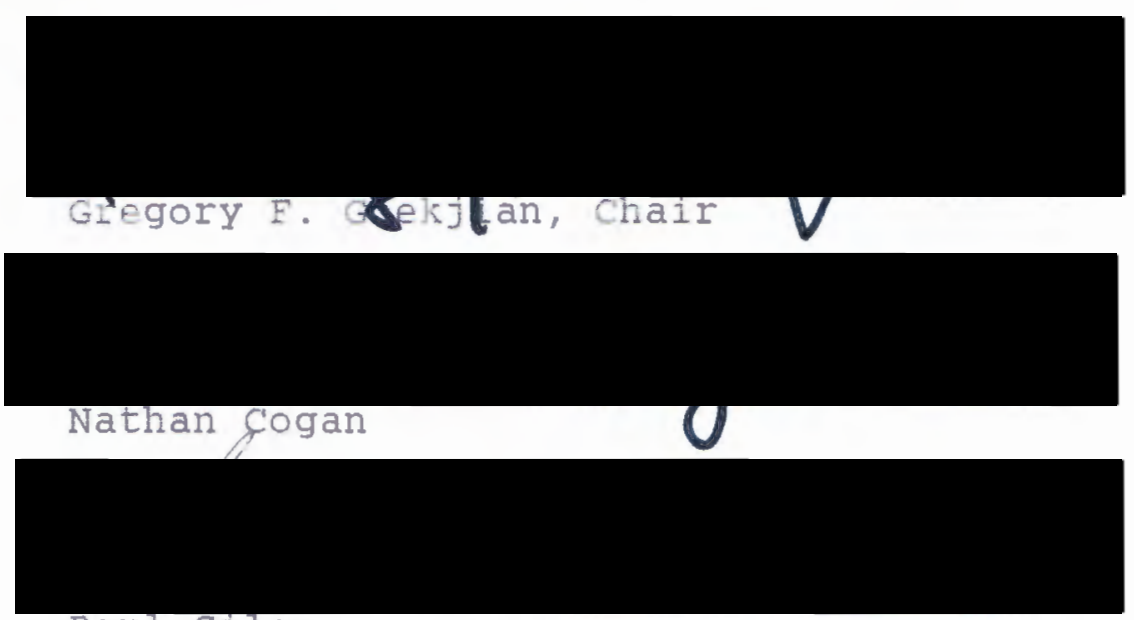

Paul Giles

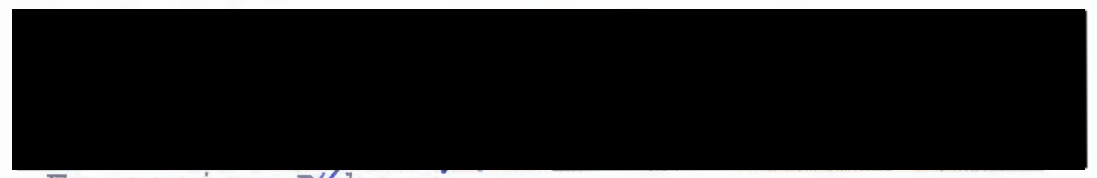

Françoise plaheau

Literary criticism dealing with John cheever focuses on the social implications of Cheever's description of suburban America. The purpose of this thesis is to propose a new approach to Cheever's short stories, and to apply the concepts developed by French literary critics Jacques Derrida and Roland Barthes to thirteen short stories by cheever. 
These stories, published between 1953 and 1973 , are "The Enormous Radio," "O City of Broken Dreams," "Torch Sorg," "The Pot of Gold, "The cure," "The Bella Lingua," "A Miscellany of Characters That will Not Appear," "The Chimera," "A Vision of the World," "Mene, Mene, Tekel, Upharsin," "The Geometry of Love," "The swimmer," and "Three stories."

This thesis proposes a semiotic approach to Cheever's short fiction, a study of signs and systems of signs. Signs are defined by Ferdinand de saussure in the cours de Linguistique Générale as the union of a signifier and a sigrified. Gilles Deleuze proposes a functional definition according to which signs serve as objects for human understandirg. I argue that the development of the stories studied, their apparent closure or lack of closure, results from the presence of signs at the "surface" of the text, and from the way in which the characters relate to these signs.

The stories are centered on the defective reading of signs. By reading signs, the characters try to regain a social, moral, or mental balance that has been disrupted by a crisis in patterins of communication and meaning. The characters seem to hesitate between a classical conception of reading that takes them from the signifier to the signified, and a hermereutical reading based on the characters' research of the plurality of meaning. Here, one may refer to the texts of Jacques Derrida, especially to of 
Grammatoiogy and "Differance." The characters oscillate between a classical reacing of the signs and their possible "deconstruction," the erasing of the signifier that permits the "freeplay" of the possible significance of the sign.

This process sometimes destroys the characters, and sometimes rejects them in their former situation. Something pievents the characters from actually deciphering semioti: systems. In some cases the signs are pathological in their organization as it is defined by saussure. sometimes their reader is patrological, not sufficiently prepared to carry out his/her task. And sometimes signs and reader belong to two mutualiy exclusive semiatic worlds, thus making reading impossible. The characters are not able to define clearly either theix position in the semiotic system they confront, or their relation to the origin of this system.

This problem of the "genealogy" of signs reveals the metaphysical dimension of cheever's short fiction. A deeply religious man, theever speaks in his stories of men expecting to recejve signs and meseages from a metaphysical entity such as God or Fate. Yot, cheever's god is absent and often sarcastic. The characters' attempts to read signs force them to ackiowledye this metaphysical power, in the same way that the reader has to accept the writer's power in order to assign meaning to a story. As Darthes implies in s/z, "contract" between the creator and the reader of signs is recessary to assume the existence of a neaning. The pover os 
God over the characters may be a destructive power, but it is also a power that guarantees the balance of the suburban world, even if this balance implies a dull and annoying life. Cheever's stories convey a sense of disillusionment and sadness that is the price the characters have to pay for peace and serenity. 
CHEEVER'S SIGNS:

A SEMIOTIC APPROACH TO THIRTEEN

STORIES BY JOHN CHEEVER

by

LAURENT DITMANN

A thesis submittec in partial fulfillment of the requirements for the degree of

MASTER OF ARTS

in

ENGLISH

Portiand state University

1988 
TO THE OFFICE OF GRADUATE STUDIES:

The members of the committee approve the thesis of Laurent Ditmann presented May 19, 1988.

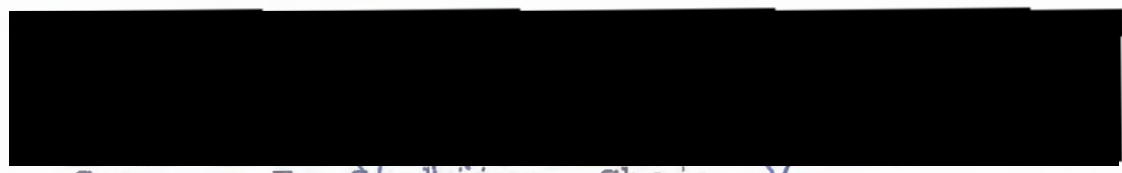

Gregory F. Gpeljian, Chair
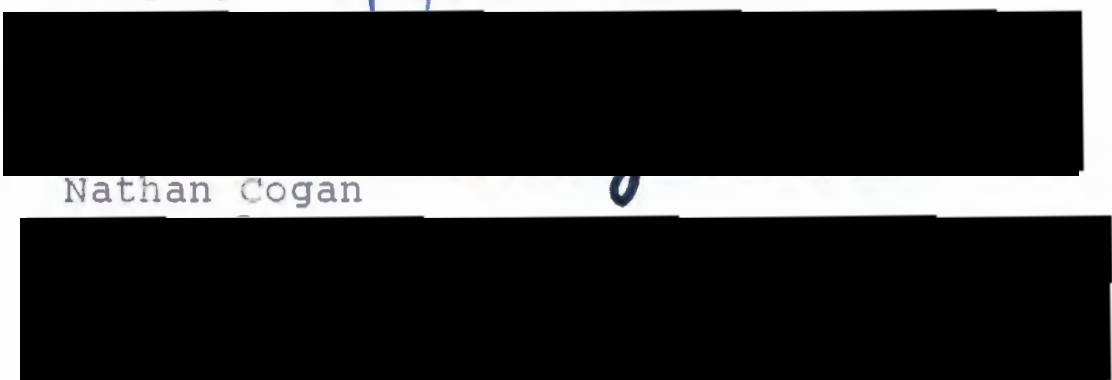

\section{Payl Giles}

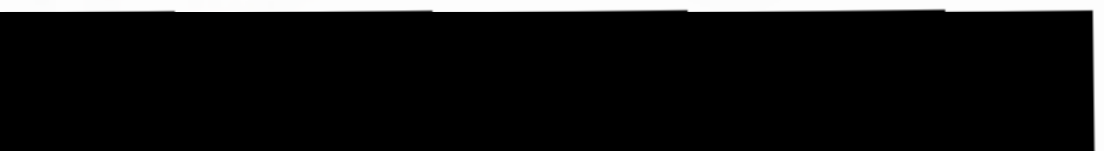

Françoise Páheáu

APPROVED:

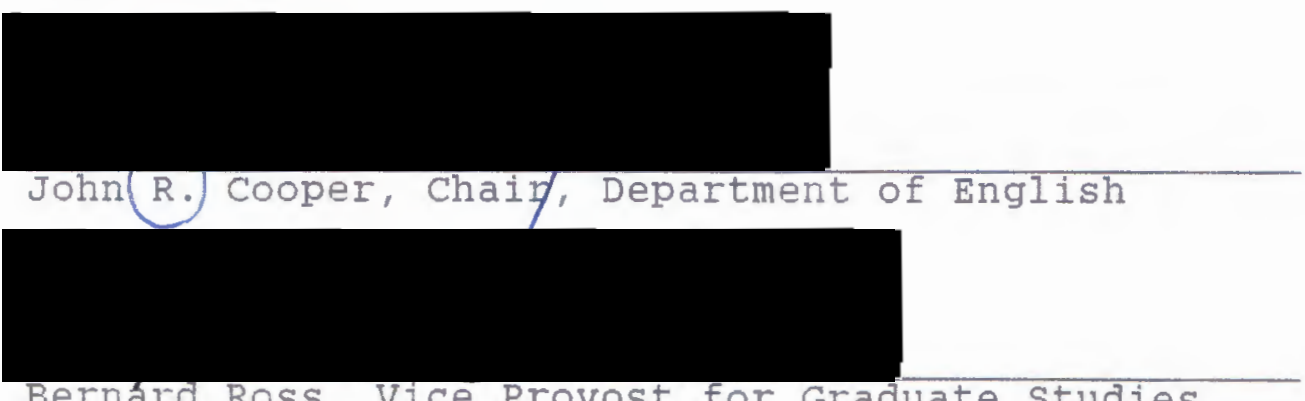

Bernard Ross, Vice provost for Graduate studies 


\section{TABLE OF CONTENTS}

CHAPTER

I INTRODUCTION: THE ANATOMY OF SIGNS . . . . . . 1

I THE READING AND GENEALOGY OE THE SIGNS . . . . 13

III PATHOLOGY OF THE CHARACTERS, PATHOLOGY OF

THE SAUSSURIAN SIGNS, AND THE IMPOSSIBILITY

OF READING . . . . . . . . . . . . . . . . 39

IV CHEEVERIAN METAPHYSICS . . . . . . . . . . . . 50 CONCLUSION . . . . . . . . . . . . . . . . . . . . . . . . . 86 WORKS CONSULTED . . . . . . . . . . . . . . . . . . . 90 


\section{CHAPTER I}

INTRODUCTION: THE ANATOMY OF SIGNS

The characters of John Cheever's short stories are not exceptional people. They are ordinary people placed in ordinary situations, and confronting ordinary problems of humar life. Many critics emphasize this quality in the description of the daily reality of modern American life. clinton Burnhams calls Cheever "a major chronicler of contemporary absurdity, especially in its upper middle-class urban and suburban manifestations." Arthur Voss says that Cheever "has specialized in writing about the tensions, frustrations, futilities, and inanities of life in uppermiddle-ciass suburbia." $z$ James scully refers to cheever as "an cracle of subccracy," 3 the American suburban world. E. p. Walckiewicz writes that he "felicitously" captures "the seriocomic essence of metropolitan and suburban angst," 4 and

${ }^{1}$ Clinton S. Burnham, "John Cheever and the Grave of Social Coherence," in Critical Essays on John Cheever, R. G. Collins ed. (Boston: G. K. Hall, 1982) 109.

${ }^{2}$ Artiur Voss, The American short story, A Critical Survey (Norman: University of Oklahoma Press, 1973) 348.

3James Scully, "An Oracle of Subocracy," rev. of The Brigadier and the Golf Widow, by John Cheever, the Nation 8 Feb. 1965: 144.

${ }^{4}$ E. P. Walkiewicz, "1957-1968: Towards Diversity of Form," in The American Short Story, 1945-1980, Gordon weaver, ed. (Boston: Twayne, 1983) 36 . 
Robert slabey adds that "Cheever's people are ordinary, foolish, shallow; for the most part lonely, sad, disappointed, inarticulate, they muddle through after barely avoiding catastrophe." 5

Most critics agree that cheever's characters are disenchanted and bitter about the urban and suburban life. For them, the American way of life has turned into a disappointing experience, sometimes a nightmare. Frank Warnke writes that Cheever is "a haunted chronicler of the impingements of an inexplicable malevolence on ordinary life." Richard Rupp summarizes this argumentation when he writes that

Cheever's heroes are less individuals than types or versions of the same experience; his innocents are either born into or move into a specious Eden. Discovering there is a corruption both personal and social, they struggle toward some spiritual reintegration, usually through marriage and the family. 7

Cheever's characters suddenly discover that they are unable to cope with the suburban reality they once knew so well and fail to recognize their environment. After having for some reason lost their social, moral, or mental balance, the characters desperately look for reassuring signs. They

${ }^{5}$ Robert M. Slabey, "John Cheever, the swimming of America," in Critical Essays 181.

"Frank J. Warnke, "Cheever's Inferno," rev. of some People, Places and Things That will Not Appear in my Next Novel, by John Cheever, The New Republic 18 May 1961: 15.

${ }^{7}$ Richard H. Rupp, "of That Time, of Those Places: The short stories of John Cheever," in Critical Essays 231. 
expect the once familiar world to speak somehow to them in order to show them a meaning in life. But to the characters, it seems that there is something wrong with the signs provided by the world. Either the signs do not make any sense, or the characters themselves are unable to use these signs to find a stable image of the world. Therefore, despite the helpful reading of a range of critics, Cheever's short stories continue to pose problem for the reader precisely because the signs are, at best, incompletly understood. Therefore, I propose to show that the problematic reading of signs is one of the mainsprings of Cheever's short stories. A more profitable reading of Cheever's stories can be gained if we use the critical apparatus developed by structuralist and deconstructionist criticism.

This type of criticism studies the organization of the appearance of the text with its meaning. What is in focus here is a particular type of relationship between the "surface" of the text and the deeper layers of its structure. This terminology, borrowed from structuralist criticism, helps to define the way in which the fates of Cheever's heroes are conditioned by the world in which they live. In the preface to The stories of John Cheever, the author refers to the way the appearance affects the surface of his stories:

These stories seem at times to be stories of a longlost world when the city of New York was still filled with a river 1ight, when you heard the Benny Goodman 
quartets from a radio in the corner stationary store, and when almost everybody wore a hat. . . . The constants that I look for in this sometimes dated paraphernalia are a love of light and a determination to trace some moral chain of being. Calvin played no part at all in my religious education, but his presence seemed to abide in the barns of my childhood and to have left me with some undue bitterness. ${ }^{3}$

Cheever insists on the notion that there is a link between the "paraphernalia" of his time and the metaphysical nature of the world in which these elements--music, light, hats--are organized. Yet cheever never describes this world with precision. It operates as a sort of background wherein the features are always a little blurred. Cheever never studies place, time, colors, names, and occupations thoroughly in his short stories. Of course, the lack of detail in the narration is often one of the characteristics of the genre. However, one may wonder if there are other structural factors influencing this form of minimalism. The allusion to Calvinism is interesting in this context. The Calvinist doctrine is based on the absolute predestination of human life. If Cheever's stories are metaphors for a form of Calvinist predestination, then their structure must include the elements necessary to a "literary predestination." This concept implies the existence of a link of necessity (in the philosophical sense of the term) between the development of the narrative and the signs therein.

BJohn Cheever, The short stories of John Cheever (New York: Ballantine, 1980) $\mathrm{x}$. 
The predestination of the text results from the way in which the characters "read" small fragments of information placed in their paths. All the songs, clothes, places, names, and literary references function as signs provided by Cheever for his characters. The characters follow and interpret these signs and the short story consists of the progress in the characters' interpretation. In the Barthesian vocabulary, these signs are found at the surface of the text. This surface is linked to the deeper layers of its structure. To define this relationship between the surface and the depth of the text, one must examine the signs which have a misleading influence over the characters' lives and over their interpretation of the world.

The first issue to address is the nature of signs. signs result from human activity, and they also influence this activity. As Jacques Derrida points out, "we take or give signs."s They are a means of representation and communication constituting the basis of human language. According to Julien Greimas' definition of the word, they stand for something that is not actually present ("quelque chose qui est là pour représenter autre chose"). 10 Signs form a "message" which is generated, encoded, and ultimately deciphered and read.

'Jacques Derrida, "Différance," in Critical Theory since 1965, Hazard Adams and Leroy searle eds. (Tallahasse: Florida state University Press, 1986) 124.

10 Algirdas Julien Greimas, Dictionnaire Raisonné de la Théorie du Language (Paris: Hachette, 1970) 350. 
To understand this process, one must refer to Ferdinand de saussure, and to his Cours de Linguistique Générale. For saussure, signs pertain to the domain of utterances. They are the union of a "concept" and of an "acoustic image."1 The term of union is important because it emphasizes the fundamental characteristic of signs: they are dichotomous entities ("une entité psychique à deux faces"). ${ }^{12}$ The first side of this double-sided "anatomy," immediately perceived by the mind of the interlocutor, is referred to by saussure as "signifier" ("signifiant") and the "concept" as "signified" ("signifié"). ${ }^{13}$ First of all, saussure stresses the link between signifier and signified as being purely arbitrary. Secondly, because the signifier pertains to utterance and audition, it is perceived in a chronological sequence. It is defined as a linear function of time. These two facts greatly influence the way in which, according to saussure, signs fulfill their function. The association between the utterance of a sign and its reading is not "free," but "forced."14 It is regulated by a system of rules forced on the individual by the linguistic community ("masse parlante"). ${ }^{15}$ The individual cannot

${ }^{11}$ Ferdinand de saussure, cours de Linguistique Générale (Paris: Payot, 1978) 97.

\footnotetext{
${ }^{12}$ Saussure 99.

${ }^{13}$ Saussure 99.

14 Saussure 104.

${ }^{15}$ Saussure 112 .
} 
develop a different interpretation of the same sign because it would render communication impossible. It is only time, the diachronic, which affects signs. It may redefine, always arbitrarily, a somewhat different relationship between signifier and signified than existed before and after ("déplacement de la relation entre le signifié et le signifiant"). ${ }^{15}$

Saussure contends that signs present themselves in a coherent organization. Referring to the organization of language, saussure calls it a system ("système de la langue"). ${ }^{27}$ The word "system" may also be used as defined by Greimas: "un tout cohérent dont les éléments dépendent les uns des autres."1B saussure further develops his analysis of the linguistic system, stating that a system consists not only of its basic elements but also of the relationships of association and opposition between these elements.

According to Greimas' definition, the saussurian system of language includes two levels: utterance ("expression"), and content ("contenu"). But each level shows the existence of semantic and phonemic sub-systems. systems are not always entirely independent. They can include sub-sets and can be themselves included in broader systems. Words--linguistic

$$
\begin{aligned}
& { }^{16} \text { Saussure } 109 . \\
& { }^{17} \text { Saussure } 107 . \\
& { }^{2} \text { Greimas } 385 .
\end{aligned}
$$


signs--are only one type of sign. Human activity creates other types of signs that can be defined as objects of study for saussure's science of signs, "semiology."19

Edith Kurzweil states that semiology,"the science that shows what constitutes signs and what laws govern them," expands into Derrida's semiotics, "the general philosophical theory of signs and symbols that deals with their function in both artificially constructed and natural languages."20 The world as we perceive it is full of semiotic systems. I use the word "semiotic" in the meaning of "pertaining to semiotics" and according to the definition of semiotics ("sémiotique") in Josette Rey-Debove's Lexique de Sémiotique:

science qui étudie tous les phénomènes de culture comme s'ils étaient des systèmes de signes, en se basant sur l'hypothèse que, en réalité, tous les phénomènes de culture sont des systèmes de signes, c'est-à-dire que la culture est essentiellement communication. ${ }^{21}$

This definition implies that signs are not inert structures. Since they participate in processes of communication and are part of organic systems, they appear as dynamic elements. Having introduced an anatomical definition of signs, and in the same way that medicine differentiates descriptive

${ }^{29}$ Saussure 33.

2 ogdith Kurzweil, The Age of structuralism (New York: columbia Press University, 1980) 6 .

21 Josette Rey-Debove, Lexique de Sémiotique (Paris: Presses Universitaires de France, 1979) 130. 
anatomy and physiological or functional anatomy, I may now suggest a functional definition of signs.

Signs form systems that serve as objects for human understanding. The human mind does not think autonomously. It needs a stimulus that triggers the intellectual process. The world is a source of signs, of things to think about. This idea is found in Gilles Deleuze's essay Marcel Proust et les signes, when he writes:

l'acte de penser ne découle pas d'une simple possibilité naturelle. Il est, au contraire, la seule création véritable. La création, c'est la genèse de l'acte de penser dans la pensée elle-même. or cette genèse implique quelque chose qui fait violence à la pensée, qui l'arrache à sa stupeur naturelle, à ses possibilités seulement abstraites. Penser, c'est toujours interpreter, c'est à dire expliquer, développer, déchiffrer, traduire un signe. ${ }^{z}$

The attempt to find an intelligible structure in any phenomenon, and to include it into a system also defines signs. If one tries to "read" something, to assign meaning to something, it must be a sign, or a system of signs. If one mentally defines a system of phenomena, and if one tries to find its meaning, one defines a semiotic system. As Deleuze puts it, signs force us to think ("ce qui force à penser, c'est le signe").23 Intellectual processes and reading of signs are intertwined. This implies that a theory of signs has to include a theory of reading that will be studied in the first part of this thesis. I will study

${ }^{22}$ Gilles Deleuze, Marcel proust et les Signes (Paris: Presses Universitaires de France, 1964) 87.

${ }^{23}$ Deleuze 86. 
the concept of reading developed by Jacques Derrida to analyze the way in which the characters read signs in Cheever's short stories.

signs in Cheever's stories are ambiguous. They do not speak clearly to the characters, who therefore need a method of interpreting and deciphering the world. The characters need to develop a hermeneutical approach to the world. I use the word hermeneutical according to Greimas' definition: "[l'herméneutique] tente de dégager les sens recevables." 24 signs can sometimes be assigned two opposed meanings, as in the story "Torch song." This ambiguity of signs and systems of signs in Cheever often destroys the main character who becomes lost among a plurality of meanings. To find out how signs and the reading of signs affect the characters in Cheever's short stories, one must then study the way in which signs appear in the texts. This "genealogy" of signs is intended to show how the characters try to define semiotic systems as well as their relationship with these systems, as in "Mene, Mene, Tekel, Upharsin." Then, by studying the way in which these structures can in certain cases prevent the characters from reading them, I will suggest that a chasm is created between the characters and their environment (as in "The Chimera").

Signs should ideally render the world intelligible to the characters, but somehow they fail to do so. Is there a 
difference between saussure's conception of signs and the signs as they appear in Cheever's stories that accounts for this malfunctioning? There are three types of malfunctioning. First, the characters may be unable to interpret a functioning system, as in "O City of Broken Dreams." I will refer to this point as a "pathology of the reader," since it pertains to the functional definition of signs. Secondly, the signs may be incomplete, or form an incomplete system, in which case the anatomy of saussurian signs is not respected, illustrated in "The cure" as well as in "A Vision of the world." I will refer to this point as a "pathology of Saussurian signs," since it pertains to the "anatomy" of signs. Ultimately, the reader and the semiotic system may function well but incompatibly. I will refer to this point as "impossibility of reading," an example of which is "The Bella Lingua." Cheever's characters play a game of deciphering the world. The malfunctioning of the hermeneutical process occasionally makes this game appear as a trap for the characters, because the characters discover at the last minute that there is something wrong with signs, as can be seen in "The Geometry of Love."

What comes to focus here is Cheever's conception of metaphysics. For instance, in "The Enormous Radio," the signs provided by the world may trigger a process of ethical revelation. More broadly, they may make the characters think about the conduct of their lives and their relationship to Fate and God, as in "The Swimmer" and "The 
Pot of Gold." The characters play a game of deciphering the presence of metaphysical elements in the world, but this game is rigged. Ultimately, I will examine this rigged game of deciphering played between characters as well as between the author and the reader of the short stories. I will demonstrate that cheever offers his reader pathological stories, and further, that reading them makes us pathological readers, because we too are sometimes misled by Cheever. 
CHAPTER II

THE READING AND GENEALOGY OF SIGNS

In the world, signs appear as a given. However, in a literary text, signs are selected by the writer, and one must assume a certain level of intention in the process of selection. In a text, signs do not simply hold significance: they are also meant to do so. They convey a denotative meaning, which is univocal and fixed, as according to Greimas definition of the word: "un terme est dit dénotatif lorsqu'il recouvre une définition qui vise à épuiser un concept du point de vue de son extension."25 Signs are also connotative, i.e., they convey a certain meaning sometimes independent of the writer's intention. Greimas writes:

un terme est dit connotatif si, lorsqu'on dénomme un de ses attributs du concept considéré comme du point de vue de sa compréhension, il renvoie au concept pris dans sa totalité. Le (ou les) attribut(s) pris an considération relevant soit d'un choix subjectif, soit d'ure convention de type social, la connotation est un procédé difficile à cerner. ${ }^{26}$

The study of signs is also the study of this network of possible secondary meanings. As Roland Barthes puts it in $\underline{S / Z}$,

others (the semiologists, let us say) contest the hieraichy of denotated and connotated . . . Then,

25 Greimas 89 .

${ }^{26}$ Greimas 62 . 
what is a connotation? Definitinally, it is a determination, a relation, an anaphora, a feature which has the power to relate itself to anterior, ulterior, or exterior mentions, to other sites of the text (or of another text): we must in no way restrain this relating . . . . Topologically, connotation makes possible a (limited) dissemination of meaning. ${ }^{27}$ Moreover, signs are designed to work together and to define clusters and patterns. It is the recurrence of such patterns that allows Barthes to apply semiology to a short story by Balzac in $\underline{\mathrm{S} / \mathrm{Z}}$. Barthes shows that signs are organized in systems (garment system, food system, etc.). Each system corresponds to a "code," which means that the writer, voluntarily or not, has encoded a certain piece of information in each sign which is addressed to the reader. The process can be reversed, and the signs can then be deciphered according to the five codes defined by Barthes (hermeneutic, semantic, referential, proiaretic and symbolic).

of course, one may very well contest that the categories as defined by Barthes are arbitrary themselves. The reader assigns each sign to a code, and each assignment may vary. The question of whether or not the bridge between the signifier and the signified is arbitrary can be resolved by a study of the way in which the reader shifts from one pole to the other. signs are not inert entities. Their structural properties influence and are influenced by their functional properties.

${ }^{27}$ Roland Barthes, S/Z (New York: Hill and Wang, 1974) 7-8. 
At this point, Susan Handelman's The slayers of Moses can help us to define two major orientations in the theory of reading. Handelman calls the first one a classical or Patristic orientation. It is based on the philosophical systems of Plato and Aristotle. According to the ancient Greeks, the word is a reflection of the object's form. Although it does not convey the object's truth, and although there is a certain gap between the word and the object's essence, words can still be used to approach truth. Expanding Plato's point of view, Aristotle demonstrates that language is generated by logical, mathematical rules. It is a tool to approach truth in a systematic manner. To use the correct word in the correct structure is to speak well. To speak well is to think well, and truth can be attained only by the one who thinks well. The most important characteristic of classical thought is that, as Handelman puts it,

despite his differences with Plato, Aristotle agrees that the realm of words is not a realm of meaning and truth. Discourse and being are not coterminous. ${ }^{28}$ Handelman shows how this conception of language influenced the development of a christian reading of sacred texts. It enabled the Fathers of the Church to oppose the "spirit" (the visible, the connotative) of the texts to their "letter" (the intelligible, the denotative). The 
second mode of reading, in Handelman's terminology, is the "Rabbinic" approach, which does not recognize such a distinction. Based on the idea that the Torah defines the laws of the universe instead of verbally reflecting them, the Rabbinic reading of signs implies that Truth is not only enclosed but also generated by the text, which is the word of God in action:

the written text is not only the enclothing of the fiery preexistant letters in which are contained the secrets of the creation, but with the proper methods of interpretation, one can unlock the mysteries of all being. ${ }^{29}$

This conception of scripture implies an hermeneutical approach to the text. This means that the text, since it proceeds from the divine essence, is necessarily unintelligible to the common mind and has to be deciphered and interpreted. According to Handelman, this Rabbinic interpretation of the word is echoed in the theories of modern critics such as Paul Ricoeur and Jacques Derrida. Derrida's approach to signs proceeds from the idea that the signifier and the signified are not pinned together and that they are always perceived in terms of "différance." This term has a double meaning. It derives from 'différer,' "to be not identical, to be other, discernible."3o But the same verb also means "to temporize, to take recourse, consciously or unconsciously, in the temporal and temporizing mediation

29 Handelman 38 .

30 Derrida, "Différance" 123. 
of a detour."31 Jonathan Culler summarizes and comments on this point:

this irresolvable dialectic [discussing a semiotic system-describing a semiotic system], . . . Derrida captures with the term 'différance,' which is both a difference and a differing, designating a passive difference always already in place as the ground of signification and an act of differing which produces the differences it presupposes. ${ }^{32}$

we cannot attain directly the signified through the signifier. The signifier, the letter, produced by writing, is not nature itself. For Derrida, the letter only represents and signifies "presence":

the sign represents the present in its absence. It takes the place of the present. When we cannot grasp or show the thing, state the present, the being present, when the present cannot be presented, we signify, we go through the detour of the sign... . The sign, in this sense, is deferred presence. ${ }^{3} 3$

Therefore, the reader must go "around" the letter. Meaning results from the absence of the letter, its "rupture, fragmentation," and "discontinuity."34 Reading proceeds by erasing and "differing" the signifier, the letter:

only pure absence--not the absence of this or that, but the absence of everything in which all presence is announced--can inspire, in other words, can work, and then make one work. . . . The pure book, the book itself, by virtue of what is irreplaceable within it,

${ }^{31 D e r r i d a, ~ " D i f f e ́ r a n c e " ~} 123$.

32 Jonathan Culler, The Pursuit of Signs (Ithaca: Cornell University Press, 1981) 41 .

33Derrida, "Différance" 124.

${ }^{34}$ Handelman 176. 
must be the "book about nothing" that Flaubert dreamed of. ${ }^{35}$

Cheever's characters search a method of interpreting the world. But, whereas the classical method of reading fails to comfort them, the Rabbinic or Derridean method is beyond their reach. They are confronted by many signs, which they try to interpret to obtain the truth of their position in the world. They try to organize these signs by the force of their intellect into a significant system. This point is illustrated in "Torch song," a story which shows that the reading of signs is a pivotal point in Cheever's short fiction. The story consists of a shift from one interpretation of a given sign by a character to another, opposite meaning. The narrative mainspring is a reinterpretation of the sign which gives rise to a reinterpretation and reorientation of the character's world.

In "Torch Song," two characters, Jack Lorey and Joan Harris, who have nothing particular in common, meet regularly in New York City throughout the 1930s and 1940s, to the point that Jack seems to think that there is some kind of privileged link between her life and his own. Jack's impression is expressed as soon as the story begins: "he began to think of her as the widow. She always wore black, and he was always given the feeling, by a curious disorder in her apartment, that the undertakers had just

35 Jacques Derrida, "Force and Signification," in Writing and Difference (Chicago: The University of Chicago Press, 1978) 8 . 
left". ${ }^{36}$ obviously, the black Joan wears, both material and meaningful, is a sign of death. Death seems to be her constant companion.

There is no conventional plot in the story: its structure is provided by the several encounters between Joan and Jack, each encounter involving the death of Joan's partner at the time. This is an essential characteristic of Cheever's craftsmanship. Cheever says in an interview with Annette Grant:

I don't work with plots. I work with intuition, apprehension, dreams, concepts. . . Plot implies narrative and a lot of crap. It is a calculated attempt to hold the reader's interest at the sacrifice of moral conviction. . . But a good narrative is a rudimentary structure, rather like a kidney. ${ }^{37}$

The absence of plot is based on an accumulation of incidents which the main character tries to interpret. He expects to find a closure to the events in which he is involved. As John Gerlach points it out "the expectation of closure can shape the structure" of the short story. ${ }^{38}$ Jack bases his conviction on the recurrent presence of Death in all his encounters with Joan.

Jack always regards Joan as a victim of the deaths that form the basis for their meetings, not their cause. It is

${ }^{36}$ Cheever 105.

37John Cheever, interview with Annette Grant, in Critical Essays on John Cheever, R. G. Collins ed. (Boston: G.K. Hall, 1982) 93 .

$38 \mathrm{John}$ Gerlach, "Closure in Modern Short Fiction: Cheever's 'The Enormous Radio' and 'Artemis the Honest well Digger," " in Modern Fiction Studies 28 (1982):148. 
his way of "reading" Joan as a sign and of plugging into a coherent system the incidents he witnesses. When Jack meets her after her affair with a Swedish count, which ends up in an abortion, he feels "shocked to think of the innocent girl from ohio having lived with a brutal dope addict and traded with criminals."39 Joan is not perceived by Jack as a representative or agent of death, but simply as the victim of persecution ("it angered Jack to think of this big, splendid girl's being persecuted by her neighbors"). 40

By the end of the story, Jack's interpretation of the situation is completely reversed. Jack is undergoing the last stages of a long process of social and physical decay. Furthermore, he then identifies Joan's presence as the embodiment of death itself. When, for the first time in the story, Joan visits Jack, who is seriously ill, he observes "that lewd and searching shape of death came there to find him in the evening."41 The process of the story makes him go from one interpretation to another that is radically different. But the object of this interpretation is the same throughout the story, and the process of forcing it to make sense is also the same in the beginning and in the end of the story. It is the same woman who is first seen by Jack as an elegant model, and finally as a woman dressed

\footnotetext{
${ }^{39}$ Cheever 107.

${ }^{\circ}$ Cheever 113.

${ }^{41}$ Cheever 122.
} 
"like a crow." The original sign of death is not interpreted in the same manner at both ends of the story; this shift from one reading to the other proves to be the story's pivotal point.

In "Torch song," Jack is the witness to a chain of incidents and episodes out of which he finally derives a complete meaning. The signs he reads as independent units are linked together by Joan's presence. This presence creates a coherence of signs that Jack does not perceive at first. However, something in the text prevents him from understanding the system of signs. Jack goes from one reading to the other, and this oscillation destroys him. His first approach is marked by the belief that the world is not exactly as it appears. Joan has to be more than a woman. She must also convey a meaning intelligible to Jack. Yet, at the same time, Jack refuses the possibility of Joan corresponding to that which she looks like--death. Jack applies an hermeneutical system, but refuses to acknowledge its metaphysical consequences. Jack seems to vacillate between two opposite readings of Joan, the persecuted woman and the killer, at a point when he needs and wants to have a clear vision of the world. His mental image of Joan corners him so that, ultimately, he is forced to adopt the exact opposite view. 
Handelman insists on the idea that "the movement of Rabbinic interpretation is.. . from sense to sense."43 Jack's destruction is caused by his refusal of this plurality of interpretation of signs. Jack uses a method of reading for which he is not prepared. Greimas says in his definition of "hermeneutics": "elle présuppose ainsi une position philosophique de référence comme critère d'évaluation."44 Nothing in the text indicates that Jack holds such a philosophical standpoint. Therefore, the actions lead to the fact that the intellectual process triggered by the presence or undecidability of the signs destroys the main character of this story.

Is this a constant in other cheever stories? It seems to be so when one considers texts such as "The Enormous Radio" and "The Geometry of Love." Yet, story titles such as "The Cure" and "A Vision of the World" seem to imply that the reading of signs can lead to a successful and stable positioning in the world. The literary genre of the short story predisposes the writer to accumulate individual signs: since the short story has to be kept short, the writer has to provide as much information as possible in signs which bear meaning without the author providing any explanations. In a short story, the semiotic units which Barthes calls in $\underline{\mathrm{S} / \mathrm{Z}}$ "blocks of signification"45 are reduced to their

4 Handelman 21.

4 Greimas 171.

45arthes, $\mathrm{S} / \mathrm{Z} 13$. 
smallest possible form, that of elementary signs. Cheever agrees with such a conception when, alluding to the way he writes short fiction by creating an "instant" short story in a magazine article, he writes: "you can't put this scene in a novel."45 This interpretation is also corroborated by the title of his fourth book of short stories: some People, Places, and Things That will Not Appear in my Next Novel. ${ }^{47}$ The novel implies a sense of development that the episodic nature of the short story will not bear. Regarding this point, Adam Gussow writes:

The brilliance of his [Cheever's] stories is due in no small part to their perfect ratio of specification to specialization, of the particular fictional world being evoked to the meanings that his style is able to distill out of that world and fuse with it. ${ }^{48}$

This is why Cheever's short stories are full of signs. signs surround the characters and provide them with a background. This background provides the "space" of the story, in which these characters function so as to read these signs. But how do signs appear in this space? If one considers the story first analyzed, "Torch song," the parameters of the space of the story are defined in the very first lines by an accumulation of names and activities:

45John Cheever, "Why I write short stories." Newsweek 30 oct. 1978: 25-25.

4 John Cheever, Some People, Places, and Things That Will Not Appear in my Next Novel (New York: Harper and Row, 1961).

48Adam Gussow, "Cheever's Failed Paradise: The shortstory stylist as Novelist," Literary Review 27 (1983): 111. 
"they were of the same age and during their first summer in the city they used to meet after work and drink Martinis in places like Brevoort and Charles', and have dinner and play checkers at the Lafayette." 49 The characters are simply introduced as names, with very little information about their pasts or their occupations. Characters are placed in contrast with this stacking of signs that constitutes their environment. They are placed a priori in a complex but imprecise system of signs. These signs seem to define arbitrarily a sort of impressionistic semiotic scenery.

Cheever's signs are aleatory and arbitrary. In the conditions of its own production, "Torch Song" already includes a major paradox: the signs that are given to the characters to be read seem not to make any sense. The language of signs seems to be illogical, and this first leads Jack to the conclusion that the world has to be deciphered. But it takes him "a few years"50 to make this decision. In the meantime, he seems to accept the somewhat chaotic semiotic background without questioning it.

Jack's predicament results from the fact that he cannot conceive a complete system of signs that would deny him the right to exist. He looks for a link of any kind between the system and himself. Although he does not comprehend the system, he wants to have a space in it. His own part in the

${ }^{49}$ Cheever 105.

50 Cheever 105. 
functioning of the semiotic system causes him to hesitate in his interpretation of this system. This means that the system can function only if Jack accepts, passively or actively, participation in it. signs cannot function independently. Signs receive an increased meaning insofar as they affect people's lives. They form patterns and structures of time, place and action by their juxtaposition and superposition. It is this organization that we try to determine when we read signs.

Reading, therefore, is related to the determination of a point of origin. The reading of signs is a research of their "genealogy." The organization of signs in systems is either within us or outside us. We are part of it or we are negated by it. The hesitation between two readings proceeds from the nature of the semiotic system. According to Derrida, there are two ways to conceive a structure. The "classical" conception implies the existence of a "center" or point of origin of the system. Derrida adds that

the function of this center was not only to orient, balance, and organize the structure--one cannot in fact conceive an unorganized structure--but above all to make sure that the organizing principle of the structure would limit the free-play of the structure. ${ }^{51}$

He also points out that

the concept of centered structure is in fact the concept of a freeplay based on a fundamental group, a

51 Jacques Derrida, "structure, sign, and Play in the Discourse of the Human sciences," in The structuralist Controversy, Richard Macksey and Eugenio Donato eds. (Baltimore: Johns Hopkins University Press, 1970) 247-8. 
freeplay which is constituted upon a fundamental

immobility and a reassuring certitude, which is itself beyond the reach of freeplay. 52

Yet another conception of the center of a system is possible, based on the concept of "différance." By dislocating systems of signs, allowing the "freeplay" to take place, and reading the signs by difference and absence instead of "reducing or deriving the signifier,"s3 one may conceive a system in which the center "could not be thought in the form of a being present" and "had not natural locus."54 According to Barthes, such a system is not an abstraction. It can be found, for instance, in the cultural patterns of the Japarese society which he studies in Empire of Signs. ${ }^{5}$ But Cheever's characters are too far from such a cultural system. Their attempts to define a system with an empty center first make the signs lose their chaotic nature, but they are ultimately doomed to fail. By attempting to read signs, the characters affirm the existence of a system and pose themselves as part of the system.

Defining a system poses the existence of an "inside" and an "outside." This distinction is made by Derrida when he comments upon saussure's point that writing only represents language ("langue et écriture sont deux systèmes

\footnotetext{
5 Derrida, "Play" 248.

53 Derrida, "Play" 251.

${ }^{54}$ Derrida, "Play" 249.

${ }^{55}$ Roland Barthes, Empire of Signs (New York: Hill and
} Wang, 1982). 
de signes distincts; 1'unique raison d'être du second est de représenter le premier"). ${ }^{55}$ According to Derrida, this exteriority of writing to language implies that we have been conditioned by western thinking to perceive writing as a threat and as an intrusion of the outside system: "for Saussure, it [writing] is even a garment of perversion and debauchery . . that must be warded off. . . by the good word."57 Derrida's conception of writing is based on the icea that the inside and the outside, the signifier and the signified, are exchanged. Writing must ceased to be considered as an intruder, because it "comprehends language. $" 5 \mathbf{8}$

The characters $100 k$ for a position in a system, and tris quest constitutes a time of crisis. A crisis is not oniy a type of behavior, it is, as Roland Barthes puts it in S/Z, a "cultural model."sg A crisis is a time of transgression of the patterns of communication and meaning. The crisis is triggered by a social situation, yet its causes and effects are related to signs. Derrida says that the new concept of system has been introduced by such a crisis: "this moment was that in which language invaded the universal problematic."so Cheever's characters have to face

56 Saussure 45 .

57 Jacques Derrida, of Grammatology (Baltimcre: Johns Hopkins University Press, 1974) 35.

${ }^{58}$ Derrida, of Grammatology 7 .

${ }^{59}$ Barthes, $S / Z 52$.

Goperrida, "Play" 249. 
such an invasion of signs and try to resolve it. Either the crisis is resolved by a return to a status quo ante, a restoration of the original system of signs, which is illustrated by "The Chimera," or it destroys the characters' original systematic vision of the world and provokes in reaction the genesis of other systems of signs.

The latter is the situation of the narrator in "Mene, Mene, Tekel, Upharsin." The development of this unusual story (a third of it is composed of embedded tales not "produced" by the narrator) can be compared to that of "Torch Song." Again, the text is fragmented into a series of episodes in which an anonymous narrator witnesses the appearance of signs. But in "Mene, Mene, Tekel, Upharsin" the signs are more explicit: they are texts, graffiti found by the narrator in stations and on trains. The first message found in Grand Central station in New York City is significant:

The marble was light brown--it might have been a giallo antico, but then I noticed Paleozoic fossils beneath the high polish and guessed that the stone was a madrepore. The near side of the polish was covered with writing. The penmanship was legible, although it had no character or symmetry. What was unusual was the copiousness of the writing and the fact that it was organized into panels, like the pages of a book. I had never seen anything like this before. My deepest instinct was to overlook the writing and study the fossils, but isn't the writing of a man more lasting and wonderful than a paleozoic coral? I read. ${ }^{\circ}$

The narrator finds signs, or something that looks like 
signs, assumes that they are intentionally addressed to him, and tries to find their meaning.

The narrator found these fossils of writing on the table of a restaurant. This passage equates the literary message to the dessicated form of an organic life. Writing is first perceived as an invasion of death. This message functions as a link between what is now dead (the writer or writer's intention) and what is now in force (the reader's understanding). The writer is anonymous and his reader is both anonymous and arbitrary. Everything participates in a effort to make the message inoperative, to empty it of its meaning, to deprive it of all the necessary characteristics of a story. Its narration is completely deprived of referential element (time, space, or characterization). Moreover, the character does not even read all of this first text he encounters.

Nevertheless, he can still appropriate the text and relate to it in terms of personal experience: "I was tired and in some way disarmed by the fact that I had not been at home for years."5z Two reasons may account for this paradox. First, if one accepts the idea that Cheever's character felt the necessity to read the world by difference, one sees how death, because it is absolute absence, is also "the condition of the possibility of the sign."s3 Moreover, Derrida argues the necessity to address

${ }^{2}$ Cheever 655 .

${ }^{6}$ Harvey 66. 
the sign to a given person. Commenting on Lacan's interpretation of Poe's "The purloined Letter" and on the statement that the "letter" always reaches the person to whom it is addressed ("c'est ainsi ce que veut dire "la lettre volée," voire "en souffrance," c'est qu'une lettre arrive toujours à destination"), 64 Derrida explains that the signifier, "its materiality and its formality," does not need to be addressed. It may or may not arrive at its destination, but will one way or the other remain a sign:

a letter can not always arrive at its destination. Its "materiality" and "topology" are due to its divisibility, its always possible partition. It can always be fragmented without return . . . . Not that the letter never arrives at its destination, but it belongs to the structure of the letter to be capable, always, of not arriving. ${ }^{55}$

In this story, the arbitrary and random nature of signs does not prevent the narrator from assuming the existence of a semiotic system.

This system of signs generates a whole world of meaning, even though it is incomplete and not entirely read. Although the reader/narrator refers to it as "gibberish," 66 he can still use it in order to address questions that allow him to redefine the world as he perceives it, his relationship to this world, and the possible relationship

54 Jacques Lacan, "Séminaire sur 'La Lettre Volée, " in Ecrits I (Paris: Seuil, 1966) 53 .

55 Jacques Derrida, The Postcard (Chicago: University of Chicago Press, 1987) 444 .

${ }^{60}$ Cheever 655. 
between tire writer of the graffiti and this world: "was this a sign of some change in the social climate or some new force of repression? or was it simply an indication of the fact that man's love of florid prose is irresistible?" Here, the functional definition of the signs is respected: they make their reader think.

The addressed questions can be approached only once another message has been found. The existence of a systen can be assumed by the namator only if several elements can be associated together. The second message has the same characteristics as the first: found in a station, it is also anonymous and written or marble. emblem of communication between a dead society and the modern world. But one difference deeply affects the second narrative: this time, the reader decides to carry out his deciphering mission and assign meaning to the entire story. There is a change ir. the reader's state of mind that calises him to read the entire tale. This attitude is based on a metaphysical decision which cheever announces through an allusion to a religious vocabulary: he gives explicitly to the station the denotation of a religious building: "the station there-proportioned like a cathedral and lit by a rose window-is a gloomy and brilliant example of that genre of architecture that meais to express the mystery and drama of travel and separation."Bs This denotation is reinforced by a network

\footnotetext{
6 Cheever 656 . 6 cheever 656 .
} 
of mystical connotations: "the colors of the rose windows, limpid as a kaleidoscope, dyed the marble walls and the waiting passengers. . . An old man slept in a pool of yellow light."6s This mystical setting allows cheever to introduce the central theme of the story, that of "prophecies."70 signs here become religious links between the past and the future through the present. They have to be deciphered entirely because they announce the future to Cheever's characters and assign meaning to his entire life.

This second message is a story of a young man who enjoys secretly visiting the park of his employer's estate. one day he saves his employer's daughter, Emily wallow, who has been bitten by a snake. Ultimately, in spite of his animosity towards the narrator, wallow makes him his heir just before his death. But Emily has fled from the mansion and the narrator remains there alone. The story includes numerous biblical references (a snake, edenic lawns and fountains), and has a clear moralizing intention. Why, then, is it rejected by the narrator? Because its "puerility" makes him feel "appalled" and "sick,"71 whereas

s9 Cheever 656 .

7o"And so God sent those fingers to write this message: 'Mene,' 'Mene,' 'Tekel,' 'Parsin.'

This is what it means:

Mene means 'numbered' -God has numbered the days of your reign, and they are ended.

Tekel means 'weighed' -you have been weighed in God's balances and have failed the test.

Parsin means 'divided' -your kingdom will be divided and given to the Medes and the Persians." (OT, Dan., 6, 24-28) 
the next message found by the narrator in a train-car, a few Iines dealing with the love of geraniums, is qualified as "most commanding of all." $>2$

It seems that the more empty and imperfect the signs are, the more the narrator tries to use them. The narrator refuses to acknowledge the link between his life and the signs that not only illustrate, but also reflect it. The last message ("Bright star, would I were steadfast as thou art-Not in lone splendour hung aloft the night..." ") ${ }^{7}$ in its stellar content, reflects the trip to the "city of light," Paris, that the narrator is starting. The narrator seems to ignore it. Desperately looking for reliable signs, the narrator does not see them when they are there, and uses them only when they do not make sense.

The narrator of "Mene, Mene, Tekel, Upharsin" finally accepts the messages he reads through the assumption that they must somehow create a system, and have an authorial intention behind them. In this case, the narrator defines a center or point of origin that is inside the system whereas he is outside. The open ending of the story ("my flight was amnounced, and I sailed through the eaves of heaven back to the city of light" 74 leaves open the possibility of new

\footnotetext{
72 Cheever 660 .

73 Cheever 662 .

74 Cheever 662.
} 
encounters. The "freeplay" may go on. This illustrates

Derrida's point that

there are thus two interpretations of interpretation, of structure, of sign, of freeplay. The one seeks to decipher, dreams of deciphering, a truth or an origin which is free from freeplay and from the order of the sign, and lives like an exile the necessity of

interpretation. The other, which is no longer turned towards the origin, affirms freeplay. ${ }^{75}$

Another approach studied by Cheever is the creation of a system by a character who places himself within the system as center-point of origin. "The chimera" is a story that illustrates this point. "The Chimera" deals with the creation of fiction by the human mind. It is the story of an anonymous first-person narrator whose life is slowly going to pieces ("my wife and I are terribly unhappy together, but we have three beautiful children and we try to keep things going"). ${ }^{76}$ The narrator's crisis is one of identity. He has none, whereas his wife has an established genealogy: "she is one of the five daughters of colonel Boysen, a Georgia politician who was a friend of Calvin Coolidge."77 His wife's existence deprives him of a personality and of a destiny, as acknowledged by the fact that she always takes away his "fortune cookies" in Chinese restaurants. ${ }^{7 \mathbf{B}}$

\footnotetext{
75Derrida, "Play" 264.

76 Cheever 558 .

77 Cheever 558.

${ }^{78}$ Cheever 563.
} 
This crisis of identity deprives the narrator's life of any logical organization. For him, things are literally upside down, like the clowns in the circus act that the narrator remembers in the beginning of the text: "Rosita used to balance herself on the head of Maria, skulltop to skulltop."79 To exit this senseless world, and to find "tenderness, love, loving, good cheer,"so the narrator has recourse to the creation of a fictional character with whom he develops a strong relationship. Through the creation of a "chimera," the narrator is trying to construct a new world, a new order: "I knew she [the chimera] was unreal, and yet she seemed to have some punctuality, some order, some schedule of engagements."ar.

This character is not created ex nihilo. It takes the intervention of anotiner person, who provides a name ("Lyle smythe"), sa and the intervention of a book, here a phonebook in which the narrator looks for Lyle's number. The juxtaposition of the three elements--crisis, name, written medium-provides the structures necessary to the elaboration of a new system of signs. The process of creation is asove all a process of distortion: the "tart" Lyle becomes "Olga,"

$$
\begin{aligned}
& { }^{79} \text { Cheever } 558 . \\
& \text { 80 Cheever } 560 . \\
& { }^{3} \text { Cheever } 564 . \\
& { }^{2} \text { Cheever } 760 . \\
& { }^{3} \text { Cheever } 562 .
\end{aligned}
$$


everything that the narrator's wife is not and she is nowhere where the narrator's wife is. She is the essence of what, according to the narrator, "more serious and finer things upon which to comment" should be.a a The story is the exact opposite to the narrator's life. It is everybody's dream, and the opposite to anybody's life. Cheever emphasizes the fact that the story "invented" by the narrator is not viable. The real world has to invade the narrator's fiction, and olga has to be perverted by "real" human behaviors: she is seduced by "a man from the office" who "got her drunk." ${ }^{\text {s }}$ she rapidly undergoes a process of decay: "her hair was disheveled, her dress was torn, her wristwatch was missing."Bo Finally, she announces to her "creator" that she is going back to california." olga has to disappear because she does not represent anything real. More than that, she has to be destroyed by the real world. This shows that in spite of the narrator's intention, the system he generates is not independent of the system of which he is a part. The process of creating a system of signs (here, a fictional character) is linked to that of reading real signs and rearranging them. Olga's disintegration reflects the narrator's. The world of

\footnotetext{
${ }^{84}$ Cheever 564 .

${ }^{85}$ Cheever 566.

${ }^{86}$ Cheever 567.

'7heever 568 .
} 
external signs, signs that have no origin within the narrator, is constantly present besides the narrator and watches over his shoulder. It is represented in the text by the man who watches the narrator trying to call Lyle smythe in the beginning of the story: "he seemed to represent something--conscience, or evil--and I went back to the office and never made the call."вs

The world created by the narrator is not an autonomous semiotic system. It is a re-creation of the semiotic system in which the narrator previously lived, and of which he said: "I did not invent this world."89 But this statement is reverberated by the statement made when olga is introduced: "I can't change her name any more than I can change her other attributes."so The reason why "this convergence of reality and unreality was meaningless"si is that they are the same. The only "meaning" of olga is indeed that she has to "make room for someone else."sz But all these "other" women whom the narrator may invent will always be the same. This "someone else" is the world and the characters as the narrator used to know them. His attempt to generate a system of signs intelligible to him is doomed

$$
\begin{aligned}
& { }^{8 \mathbf{8}} \text { Cheever } 651 . \\
& { }^{89} \text { Cheever } 562 . \\
& { }^{\circ} \text { Cheever } 562 . \\
& { }^{1} \text { Cheever } 565 . \\
& { }^{2} \text { Cheever } 568 .
\end{aligned}
$$


from the beginning because the crisis he went through does not annihilate the original semiotic system. It only questions its value.

Through these two stories, the quest for a genealogy of signs delineates a dichotomy: either signs have a probable, yet unknowable, origin, and their system can be assimilated, but not appropriated (the narrator remains outside); or the system of signs proves to be a failure for the character who generated it. In this case, a temporary system of signs is created. It is not viable, and if a genealogy of signs is possible in this case, it stops with the end of the story. The genealogy of signs is flawed, since the characters' only alternatives are between orphan signs and sterile ones. 


\section{PATHOLOGY OF THE CHARACTERS, PATHOLOGY OF THE SAUSSURIAN SIGNS, AND THE IMPOSSIBILITY OF READING}

The characters' attempts to read or create systems of signs are doomed. A first possible explanation is that characters are ill-equipped to comprehend the signs that the world of objects offers to them. Critics emphasize the idea that the characters of the short stories are imperfect and not fit for the world they live in. Rupp writes: "Cheever is developing characters who in their zeal for half truth destroy their sense of balance and relation."93 Joshua Gilder adds that "if characters lead less-than-perfect lives, if in fact they sometimes appear to be teetering on the edge of a spiritual abyss, this, to cheever, is the universal human condition." 94

This abyss is created by the discrepancy between the world as it is and the world as the characters imagine it to 2be. In "The Chimera," imagination appears useless because the world it creates, although it is different from the narrator's original world, is not separate. If the facts in

${ }^{9}$ Rupp 237.

94 Joshua Gilder, "John Cheever's Affirmation of Faith," Saturday Review March 1982: 18. 
the new world are different, the truth of this world is always the same. This point is made by Lynne waldeland:

He [Cheever] seems anxious to make a clear distinction between fact and truth. He has always tried to get to the motives and morality of his characters which underlie the manners and material aspects of their lives, but.. . the human truths involved seem to transcend the factual circumstance of the stories.95

Imagination is the flaw that prevents the characters from generating successful systems of signs. I want to demonstrate that it is also a disease that prevents the characters from reading any system of signs. What is imagination, in terms of semiotics and Derridean criticism? Derrida writes that

imagination is the power that allows life to affect itself with its own representation. The image represents and adds the representer to the represented, except insofar as the presence of the represented is already folded back upon itself in the world insofar as life refers itself to its own lack, to its own wish for a supplement... . The property of the subject is merely the movement of that representative appropriation. In that sense, imagination, like death, is representative and supplementary. ${ }^{96}$

Irene Harvey comments upon this point and adds:

The power of imagination, its force, is therefore the force of death. It is an economy of an exchange, a "dispossession" that is announced in its very movement.s?

126.

95Lynne Waldeland, John Cheever (Boston: Twayne, 1979)

${ }^{96}$ Derrida, of Grammatology 184.

97 Irene E. Harvey, Derrida and the Economy of Différance (Bloomington: Indiana University Press, 1986) 144. 
Imagination is a system of representation, of creating images of reality. It therefore pertains to the domain of signs. But these signs are particular: they are characterized by their "iconicity," which Greimas defines as follows: "on entend par icône un signe défini par sa ressemblance à la "réalité" du monde extérieur, en l'opposant à la fois à indice et à symbole."sa Ultimately, the effect of imagination on signs can be completed by Barthes' definition of the image: "that from which I am excluded."ss For many characters in Cheever's stories, the world in which they want to live is a world full of these "iconic" signs in which they do not belong. Their trauma results from the fact that they generate systems of signs that "look" familiar, but expel them nonetheless. They want to be part of a picture, and this desire destroys them. This intrusion into the domain of images constitutes the pathology of characters. It is the desire to be in two places at the same time, in the real world that destroys them, and in the world of images that constantly expels them. This is the case of the main character of "o city of Broken Dreams." This story tells of the misadventures of the Malloys, the family of a bus driver from wentworth, Indiana. Malloy is also an amateur writer who decides to try his luck in New York city where, he believes, his play

${ }^{9} \mathrm{Greimas} 177$.

${ }^{9}$ Roland Barthes, A Lover's Discourse, Eragments (New York: Hili and Wang, $19 \overline{78) 132 .}$ 
will be produced. Evarts Malloy is a storyteller by nature, but a poor storyteller. His narration is systematic and empty. He comes from a world where one says "rind of America" instead of "Rhine,"100 a world characterized by an immediate distortion of linguistic values. If only because of his social background and geographic origin, Malloy is a condemned writer and his family is compared to "the crew of a doomed submarine."101. From the beginning, he does not stand a chance against the universe he is about to discover. This new universe, New York City, is one of unknown machines and delights. The Malloys enjoy a world of immediate pleasures: vending food-machines, smiling bellboys and luminous movie-billboards. First, they perceive the city as a place where signs are readable and enjoyable. They intrude in a world of lights and images. They actually live in a network of images, the mental images of the notso-young writer who "hit the jackpot."102 The story generated by Malloy is the product of the world in which he thinks he lives. He reads all signs in this world according to his own code.

But soon enough, the Malloys discover that there are other rules, and that they do not belong in the reality of New York City. A recurrent theme in the story is that of

100 Cheever 48 .

${ }^{101}$ Cheever 48 .

102 Cheever 52 . 
the Malloys looking at maps, ${ }^{103}$ asking for directions, ${ }^{104}$ and getting lost geographically or even socially. For instance. Malloy ridicules himself by "getting lost" in an elevator. ${ }^{105}$ His wife also does so to when she sings a ridiculous song during an elegant cocktail party. ${ }^{100}$ The world in which the Malloys move reacts to their annoying presence by destroying their own system of value, their own images. Malloy himself is slowly deprived of every "fashionable" sign he was wearing as expressed by his agent Beatty "plucking" the fake carnation on Malloy's lapel.107 Cheever ridicules Malloy's image of the elegant man in the first pages of the story: "they were dressed, like the people you sometimes see in Times square on saturday Nights, in clothing that had been saved for their flight."1os It is obsolete and makes him unfit for the world in which he wants to live.

The world in which the Malloys intrude is an imaginary world to the extent that they perceive it in terms of clichés. Consequently, the world works at destroying their conception of time and space, slowly expelling them from the

$$
\begin{aligned}
& 103 \text { Cheever } 51 . \\
& 104 \text { Cheever } 55 . \\
& 105 \text { Cheever } 58 . \\
& 106 \text { Cheever } 57 . \\
& 107 \text { Cheever } 54 . \\
& 108 \text { Cheever } 48 .
\end{aligned}
$$


images they themselves created. Ultimately, they are expelled from the mythical world of writing, but this dismissal also affects the world they originally come from. Although they want to go back to the sounds and sights they know and understand, the arrival in New York of Mama Finelli, the subject of the play, and the threat of a lawsuit mark the point where Malloy's semiotic system is entirely invaded and colonized by the antiviral reaction of the "organism" of New York city. The Malloys have been confronted to two different semiotic systems, and both systems have rejected them. Cheever does not answer the question of their destiny: "the Malloys may have left the train in Chicago an gone back to wentworth. . . Or they may have changed, in Chicago, for a train to the west."xos The story's open ending places the Malloys somewhere between the two sides of a semiological system that they can not read. The Malloys are pathological sign readers insofar as they are foreign bodies in the organism of New York City. Moreover, they do not possess the necessary apparatus in order to impose their own system of signs. They are defeated by a stronger and larger semiotic system, but in this system, signs perfectly fulfill their function. They give a meaning to the world and make its inhabitant think about this meaning. 
It is not always the case in other stories. The character or reader of signs may be able to read signs. But then, it may also happen that signs themselves are illegible. This is what I defined as a "pathology of Saussurian signs." They sometimes appear distorted, incomplete or obscure. Two stories, "The cure" and "A Vision of the world," illustrate this point in two different manners. "The cure" is probably, along with "The swimmer," one of Cheever's most enigmatic stories. The reason for this is that it is a story in which the elements composing the narrative system are extremely blurred.

This story is seen from the point of view of a first person narrator whose name, occupation, and background are undetermined. The only thing we know is that he is going through a marital crisis ("My wife and I had a quarrel, and Rachel took the children and drove off in the station wagon") 10 and that he is a heavy drinker. Here, cheever uses the device of a near absence of reference. The main character has no personality, no originality, and therefore no meaning. The story operates as if the "cure" the main character is searching for is the recovery of significance.11x His efforts to create a system of signs that he can appropriate for himself naturally takes him towards books. However, the book he finds and starts to

$110^{\circ}$ Cheever 183.

11 Cheever 184. 
read is almost incomprehensible since it proceeds from the Oriental referential system characterized, according to Barthes, by an emptiness of its center ("I chose one by an author named Lin Yutang. . . The book seemed interesting"). ${ }^{112}$

Moreover, while the narrator is involved in the difficult task of deciphering this semiotic system, he realizes (or thinks he realizes) that he is being observed by a peeping-tom: "I was being watched from the picture window at the end of the living room by someone whose intent was to watch me and to violate my privacy."113 The process of dealing with signs, either to generate them (writing), or to take them from the other end (reading) seems to imply pathological consequences. The pathology of the saussurian sign appears in this story intertwined with that of their reader. The narrator of "The cure" experiences a semiotic fear: "I thought I knew, at last, what he was waiting to see. This frightened me."114 This fear comes from the world, the space in which signs deliver directly a meaning that this narrator has lost. In effect, the peeping-tom is immediately recognized by the narrator as Herbert Marston, a man with an identity, a family, a place and a meaning in the social world. ${ }^{115}$

\footnotetext{
${ }^{112}$ Cheever 185.

113 Cheever 185 .

114 Cheever 191.

${ }^{115}$ Cheever 189.
} 
This network of external meanings does not leave any freedom to the narrator. It forces upon him a recurrent image of death (the "hangman's noose"). ${ }^{115}$ Here again, the narrator has no choice: he must accept the idea that the signs that surround him are a necessary part of his environment, although he does not understand them. The narrator cannot appropriate another system of signs: he may only recover his former superficial identity (e.g., his former wife). The crisis is not resolved; it is erased. This is why he ultimately decides to go back to the world as he knew it. His return to normal life, a "smooth" life without any semiotic aggression ("we've been happy ever since. So far as I know, Mr. Marston has never stood outside our house in the dark")117 is one of the rare triumphs of a character in a cheever story. The narrator has been wise enough to return to his a-referential world before being crushed to death by the aggressive signs of "real life." He is is still as anonymous as in the beginning of the story, but has learned to accept the senselessness of signs, their absence of stable significance.

There is still another possibility in the typology of the pathology of signs. We have seen that according to Derrida, signs do not need to be read in order to exist as

116 Cheever 191.

${ }^{17}$ Cheever 194. 
signs. What happens, however, when a character reads something that is not conceived as a sign originally, that is not addressed to any reader? In this case, a sign which proceeds from language as a means of expression, and which could function independently of a reader's intervention, is contaminated by its reader. This case is developed by Cheever in "A Vision of the world." In this story, an anonymous narrator tries to interpret a series of flashes that he first describes as a "chain of events,"110 in a manner similar to that of the narrator of "Mene, Mene, Tekel, Upharsin." However, Cheever is careful to define more clearly what is at stake this time. The first indication is the title, that suggests that the interpretation of the chain of events will allow the narrator to find a way to generate rules for the entire universe, according to the Rabbinic conception of reading. This interpretation is reinforced by the first lines of the story, in which the narrator is placed in opposition to the chaotic forces of the universe, represented by the tide ("The tide is high. . . I am here alone"). ${ }^{19}$

The process of confrontation with the enigma of the meaning of the world is triggered by the discovery of a note found in the earth while gardening. This note is a promise a young farm-boy made to himself years ago: "I, Nils

118 Cheever 604 . 119 Cheever 604 . 
Jugstrum, promise myself that if $I$ am not a member of the Gory Brook country club by the time I am twenty five years old, I will hang myself."120 It was buried in the earth and was not addressed to the person who finds it. The note is not a message, and yet, it is perceived by the narrator as a sign, as the first element in the "chain" of signs that constitutes the story. This seems to indicate that "our most acute feelings," 121 although they may very well be expressed, have to be kept to ourselves. The inner self is not a subject for semiotic representation.

The next encounter between the narrator and a sign corroborates this interpretation. In a supermarket, he reads a shopping list compared to a "scroll"12z over another customer's shoulder. Again, the narrator appropriates a message that is not addressed to him. Although he can understand its superficial meaning, the message means nothing to him since it is not his own shopping 1 ist. In this story, the most important pathological feature of signs is that, even when they do mean something, they are of no particular consequence in the narrator's life. They mean without realiy meaning. This pathology seems to radiate from the signs encountered by the narrator. Even things that used to make sense are corrupted aid become one-sided

$$
\begin{aligned}
& 120 \text { Cheever } 604 . \\
& 121 \text { Cheever } 604 . \\
& 122 \text { Cheever } 605 .
\end{aligned}
$$


messages. In this context, the narrator's wife's words are significant: "I just have this terrible feeling that I'm a character in a television situation comedy . . . . I have this terrible feeling that I can be turned off."1z3 The senselessness of signs is like a venom that permeates the narrator's environment. The narrator has involuntarily committed a sin: he has read signs that were not addressed to him. This biblical interpretation is actually corroborated by the presence of a copperhead in his garden. The narrator's Eden is entirely threatened by the presence of signs that cannot be used. An interrogation about death has been raised by their presence, since it the function of signs to raise questions: "what I experienced was not fright of death; it was shock at my unpreparedness for this branch of death."1z4 However, it is a "sick" question, a question that makes the narrator and those around him sick, because the signs that gave birth to the question are not sane themselves.

This problem casts a doubt on the very existence of the world: "it pleased me to think that our external life has the quality of a dream."125 However, if the world has the quality of dreams, there is by no means a confusion between the real world and the world of sleep. There are some points

$$
\begin{aligned}
& 123 \text { Cheever } 606 . \\
& 124 \text { Cheever } 605 . \\
& { }^{125} \text { Cheever } 606-7 \text {. }
\end{aligned}
$$


of connection, but the character has to choose one of the two worlds. The world becomes a world of death and madness: "we seemed to be dancing on the grave of social coherence."126 It becomes rapidly unbearable, to the point that the narrator decides to "turn it off" $\mathbf{2 r}$ and to join the world of real dreams. In the world of dreams, language and signs are not a problem. All languages are equivalent, and an approximate rendition of English words is as useful as a Polish sentence. ${ }^{328}$

Yet, the temporariness of this dream-world is followed by a return to the a-significance of the real world. Once again, the main character longs for the world of sleep, a world of structure and meaning, a world in which signs are not forced to make sense, and therefore freely make sense. The rules of free association between signifier and signified do not operate anymore in the real world. The pathology of signs is caused by a forced association between them, as if the signs of the real world suffer of a birth defect. The conclusion of the story seems to indicate that the only way to deal with this physiological deformity of signs is to ignore it and to accept signs for what they are. The vision of the world is an immediate vision, a vision that cannot be questioned. It proceeds from an accumulation

\footnotetext{
125 Cheever 607.

127 Cheever 608 .

128 Cheever 609 .
} 
of arbitrary and abstract words: "Valor! Love! Virtue! Splendor! Kindness! Wisdom! Beauty!"129 The key to the assimilation of the dream world is not a questioning of this world, but a recitation ("as I recite them, I feel my hopefulness mount"), ${ }^{130}$ in the same way that in the Rabbinic approach to texts, there is a time for interpreting the prayer, and a time for reciting it. Handelman emphasizes this point when she explains that in the early stages of the development of the Rabbinic movement, the growth of "commentary and interpretation" required the creation of a method of "organizing and remembering."131 The code of the oral law of memorization and repetition/recitation of the text is also a moment of its interpretation.

It seems that in Cheever's stories, men are either too flawed or too weak to read perfectly clear signs, or they have to accept the idea that signs sometimes have to be accepted as imperfect. Yet there is a third possibility to explore. The ultimate misfortune that may occur to signs and readers in cheever's stories is that we may have a valid reader and a valid system of signs. But, sometimes, those two players are simply not compatible. It is reading itself that becomes impossible. This is the case presented by Cheever in "The Bella Lingua."

\footnotetext{
129 Cheever 611.

130 Cheever 611 .

${ }^{131}$ Handelman 44.
} 
"The Bella Lingua" is entirely placed under the sign of language and failed communication. Its very title associates two languages that are mutually exclusive. The story tells of wilson streeter, an American in Italy. streeter has to appropriate a new system of communication and to assimilate to a foreign society: "he was keenly conscious of the fact that he was making his life in a country that was not his own, but this sense of being an outsider would change, he thought, when he knew the language."132 However, Cheever emphasizes more the loopholes in streeter's command of the language than the progress he makes. For instance, streeter cannot use past tenses. He cannot relate to the past, organize a narration, account for past images. He is locked in the present, and is therefore able to use only an immediate system of signs. The books he is able to read are only children's books (Collodi's Pinocchio) ${ }^{133}$ whereas he is looking for a more metaphysical type of Iiterature (Dante's Inferno).134

streeter is unable to describe the country he lives in. There is a pathological discrepancy between his environment and the way in which he represents and expresses it. Furthermore, his several attempts to increase his control of the language fail one after the other, until he meets kate

\footnotetext{
132 Cheever 358 .

133 Cheever 359 .

134 Cheever 361 .
} 
Dresser, a tutor in whom he has high hopes. She is also an American expatriate, who only brings him closer to the American system of reference. All the signs around streeter, for instance the manners of both Kate and her son, function to prove to streeter that a complete assimilation of another semiotic system is impossible. He lives in a world where "panes of glass"135 separate him from a meaningful world. This screen operates as a filter that retains the meaning of the scenes he witnesses. When a "whore" speaks to him, ${ }^{36}$ or when he sees "a man struck by a car," 137 he is unable to derive a meaning from the scenes: "streeter wondered why it was that they regarded a human life as something of such dubious value."13日 The world in which he moves becomes completely impermeable to his analyzing capabilities.

However, the arrival of Kate's uncle is the occasion of a change in the narrative focus. Uncle George comes to "bring Kate and her sor home."139 This shift in the focus of narration is interesting insofar as it emphasizes, on the part of the uncle, the repetition of experiences similar to streeter's. The bus the uncle takes to tour the region

$$
\begin{aligned}
& 135 \text { Cheever } 370 . \\
& 135 \text { Cheever } 367 . \\
& 137 \text { Cheever } 367 . \\
& 138 \text { Cheever } 367 . \\
& 139 \text { Cheever } 366 .
\end{aligned}
$$


becomes a "fishbowl."140 This shows that streeter's experience can be generalized to any foreign body: "and he [Uncle George] recognized that he was separated only by a pane of glass from a life that was as strange to him as life on the moon."141

The situation is exactly the same for the natives. They are also separated from the tourists by a glass pane: "the people in the streets looked up at this apparition-this fishbowl of elderly Americans--with such incredulity that Uncle George's feelings were hurt. . . 'Don't stare,' he wanted to say to them."142 And when a contact between the two worlds appears possible, it is a not a viable one: the only time Uncle George establishes contact with an Italian, the latter steals the American's wallet. ${ }^{143}$ The story defines two cultural systems (two systems of signs) that work independently. They are mutually exclusive and their relationship must be terminated. Here again, the story is characterized by an open ending. The little boy leaves with Uncle George, therefore emptying a semantic space ("the place seemed that much bigger"). ${ }^{14}$ But if the boy has found the space where he belongs, Kate and streeter

\footnotetext{
10 Cheever 370 .

141 Cheever 370.

142 Cheever 371.

1. 3 Cheever 373 .

144 Cheever 378.
} 
are left at the point where they were in the beginning of the story, urable to communicate with their surroundings or with each other. Their awkward position in a world to which they do not relate affects their relationship to this world, but it also contaminates their ability to use their original system of communication: "Kate looked tired, but then she always did, and when the lesson ended and streeter stood up, she complimented him on the progress he had made."145 For both characters, nothing has changed since the beginning of the story. Because they refuse to terminate the contact, they remain "expatriates," in suspension.

From this pathology of reader and of signs and from the cccasional impossibility of reading, an important fact seems to be established. Signs are never explicit to the characters in Cheever's short stories. They speak a mysterious language. They are unavoidable, but resist the attempt to decipher them. They do not convey a meaning, but on the contrary hide it. A hermeneutical technique is needed to understand them. It is such a method that the main character of "The geometry of Love" attempts to define in his own terms.

"The Geometry of Love" is at the same time a very typical and very atypical cheever story. It is typical because it describes a man generating a semiotic system that is supposed to help him to cope with a world that he does 
not understand anymore. And it is atypical because, contrary to stories such as "O City of Broken Dreams," the narration reaches a clear cut conclusion, the death of its central character, Charlie Mallory.

This unfortunate hero is an engineer, somewhat dissatisfied with his family life, and more precisely with the misconduct of his wife. He suddenly receives a metaphysical illumination when he sees a truck bearing the name of "Euclid's Dry Cleaning and Dyeing."14s For once, the world seems to be talking distinctly to Mallory, and gives him a sign enabling him to develop a new approach to the world. Using his scientific knowledge, Mallory develops a figurative system of which the purpose is to "make a geometrical analogy for the boredom of a commuter's local, the stupidities in the evening paper, the rush to the parking lot."147 In a way, Mallory invents a new way of writing about his life. But whereas the common language is of no use to him, the universal language of geometry establishes a stable relationship between the user and his world.

However, if the efficiency of this newly defined language is not questionable at first, a closer exploration of its conditions of production shows how it really establishes a barrier between Mallory and the mundane

146 Cheever 704 .

147 Cheever 705. 
reality. First of all, the very "sign" of fate that triggered the whole process is by no means a univocal sign. It includes a pun ("dyeing/dying") that actually casts a doubt on the entire intellectual edifice Mallory builds. Moreover, it is not Mallory's perception of the world that is threatened in the opening lines of the story, but the world itself: "it was not that he had lost his sense of reality, but that the reality he observed had lost its fitness and symmetry."148 Here again, it is the world itself that is distorter, its distortion generating either distorted semiotic systems or systems of distorted signs. Third, if the semiotic system enables Mallory to encode the world, it proves inaccurate, and possibily useless, in the computation of human factors: "The afternoon's geometry had proved to him that her happiness, as well as [his wife's] and that of his children, suffered from some capricious, unfathomable, and submarine course of emotion that wound mysteriously through her nature."149

Mallory's original purpose is to illustrate his problems in order to solve them or at least "create an atmosphere of solution."Iso But his system fails because, through the creation of a space in which everything is a sign (which I will call space of hyper-significance), Mallory loses track

\footnotetext{
14 Cheever 703 .

149 Cheever 710 .

150 Cheever 704 .
} 
of the world he intends to analyze. The world's network of signs and meanings opposes and destroys Mallory's, thus triggering the disappearance of the city of Gary, Indiana. ${ }^{151}$ He experiences to the utmost point the phonemenon described by Barthes as "disreality" ("déréalité"): ${ }^{15 z}$

I experience reality as a system of power. . . . So long as I perceive the world as hostile, I remain linked to it: I am not crazy. But sometimes. . . I have no language left at all: the world is not "unreal" (I could utter it: there are arts of the unreal. . . , but disreal. ${ }^{23}$

Ultimately, Mallory himself is destroyed by the process of disreality. He becomes very ill and has to undergo surgery. He is so far away form his original world that he has actually become an element in a Euclidian world: "His emaciation forced him back to geometry, and he tried to equate the voracity of his appetite, the boundlessness of his hopes, and the frailty of his carcass."154 Having reached the other side of the structure signifier/signified he established himself, he is left without a way back. The shift in the narrative focus from Mallory to his wife may be interpreted as a second sign of failure of Mallory's system. The "universal" language of geometry dies with its user, whereas the common language of the living goes on in the world which is real only because it is the only one we have.

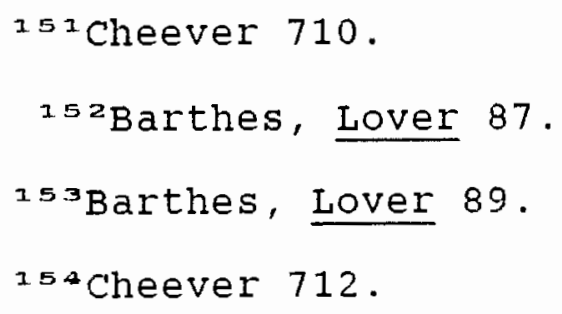


CHAPTER IV

\section{CHEEVERIAN METAPHYSICS}

Signs are a mode of communication between the world (society) and its inhabitant. The reading of these signs constitutes a sort of game of deconstruction and reconstitution. But the rules of this game have not been explained to the characters/readers. The game has not even been named. The characters and the readers only know that there is game going on. The question is to know who defined these rules and which intention is covered by the game. A mischievous being constantly places the characters in the worst possible semantic situations. Why and how is this game rigged?

Here, we are looking for an entity such as God or Fate in Cheever's stories. Although no major piece of literary criticism dealing with Cheever's religion has been written, we do know at least that the problem of the relationship to God was very acute in Cheever's life. In her book of memories of her father, susan cheever writes: "when I was young, and my father could see that something was bothering me, he used to suggest that I might try saying a prayer."15s she explatins that her father, although not religiously

${ }^{155}$ Susan Cheever, Home Before Dark (Boston: Houghton Mifflin, 1984) ix. 
educated, went back to the christian faith in the 1930s. He was even confirmed in 1955, "an act that reflected a mixture of gratitude and hope."15e she adds,

I think he hoped to find at church some sense of redemption for the sins he had committed by thought, word and deed against what he saw as the purity and innocence of the natural world--a world somehow represented by Christianity."157

She also recalls an interesting anecdote:

A black and white piece of Japarese calligraphy in a gold frame hangs on the wall of the master bedroom at the house in ossinirg. It's a quotation from the writer Kawabata, who killed himself in 1972. "Do you know what that says?" my father asked me, as he lay there the christmas before he died. I shook my head . . . "Because we cannot see him, God is everywere." 153

It seems that Cheever's God is defined by his absence rather than by his presence. The signs that the characters find in treir paths are traces of his presence. To see how this point affects Cheever's signs, one can discuss it by analogy to Derrida's conception of divine signs.

We have already seen that according to Derrida, all signs must be erased to be read. By their presence, they reveal an absence. The signifier is only the trace of the presence of a signified. Here again, the concept of difference plays an essential part: difference allows signs to exist and to be perceived by the human mind. Regarding this point, Derrida writes:

\footnotetext{
156 Susan Cheevar 167.

157 Susan cheever 167.

158 Susan Cheever 98.
} 
the trace is in fact the absolute origin of sense in general. Which amounts to saying once again that there is no absolute origin of sense in general. The trace is the differance of that which opens appearance

[l'apparaitre] and signification. ${ }^{159}$

According to Handelman, this "presence-as-separation," also found in Derrida's theory, is the key to the Rabbinic approach to God, one characterized by the idea that "Judaism is the experience of the infinitely other."150 It conditions a particular conception of the relationship between God and the scripture. In this framework, the Torah is not a material object, but the essence of the "divine wisdom enclothed therein."161 The investigation of the text is a search for a direct contact with God. Handelman writes that the "Hebrew God, however, though invisible, did not statically exist, but spoke. His Being was apprehended through 'hearing, not seeing,' through the 'divine word.' $16 z$ Cheever's God operates in a similar manner. But he is also a mischievous God who plays tricks on mortals. A first hint of the presence of such a being in the stories is the amount of irony perceptible in the misinterpretation of signs affecting the characters' lives. Everything happens as if a sarcastic fate gets a silent last word in each story.

159Derrida, of Grammatology 65.

$160^{\circ} \mathrm{Hande} \mathrm{man} 173$.

${ }^{161} \mathrm{Handelman} 37$.

${ }^{152}$ Handelman 17. 
A good illustration of this point is found in "The Pot of Gold."

This story is centered on the concept of luck, good or bad. It tells the story of the misfortunes of a young couple, Ralph and Laura, who are constantly "on the threshold of fortune."163 Like the Malloys in "O City of Broken Dreams," they are looking for success in a world they fill with images. For instance, they have on the wall of their apartment a reproduction of Van Gogh's sunflowers, the sun being here assimilated to gold and happiness. ${ }^{164}$ The "real" world constitutes only a sonic background to their expectations: "he [Ralph] knew intimately the sounds of the night street. . . the sum, he supposed, of many echoes, although, often as he had heard the sound, he had never decided on its source."165 These expectations are based on the idea that something good is mecessarily going to happen to them. They expect some metaphysical force (God? Fate?) to answer their prayers for fortune in a categorical manner. Significantly, Ralph is constantly waiting for the telephone to ring in order to receive his message of fortune. But in his desperate efforts to make things happen, he builds a rampart around his family when he invents a "Venetian blind that. . would deflect or absorb sound waves."1se His

\footnotetext{
${ }^{163}$ Cheever 122 .

164 Cheever 123.

${ }^{165}$ Cheever 124.

${ }^{166}$ Cheever 127.
} 
invention is doomed because it negates the very possibility of receiving "messages," especially if one considers that Ralph hangs the last sample of the blind at his own window. This blind materializes the screen that from this point on, instead of deflecting or absorbing messages, is going to deform them. Shortly afterwards, Ralph and Laura receive a phone call from a rich Uncle George (who echoes the Uncle George of "The Bella Lingua"). ${ }^{167}$ This is the sign of Fate the couple was waiting for. But this sign of Fate is distorted and does not really allow a valid form of communication between Ralph and George, who cannot hear each other on the phone. The message, as it is received by Ralph, implies that a certain Mr. Haadam is going to help the young couple and provide a good job for Ralph. Here, Ralph is abused by a linguistic distortion. He does not realize that fate is going to play the same trick twice, only with different names: when the ill-fated adventure of the blinds is associated with the name of Fellows, who represents any man, the second misadventure is linked to the name of the primordial man, Adam.

Two causes contribute to Ralph's failure: the rules of a world in which there are no more treasures, and the cryptic nature of the messages of Fate. Moreover, the very idea of looking for a treasure bears in itself the seeds of its failure. The "primitivism of the hunt"158 that strikes 
Ralph, but all too late, is in fact the illustration of the human inability to look for something that is not there, instead of looking at the available semiotic material (i.e., the metaphorical vision of Laura at the end of the story).

The users of signs are destroyed by their attempts to find a meaning to the world. But this destruction demonstrates that in the first place, they should not have tried to go beyond signs. Yet, the very nature of signs compels them to do so. Signs are therefore a trap. And even finding a meaning does not help the characters to master signs. Quite the contrary, an actual understanding of signs actually may be as dangerous as an absence of reading. Going beyond the gap between signifier and signified does not ensure the discovery of a way back.

This is the point made by "The Enormous Radio." "The Enormous Radio" can be regarded as a fantastic short story, as acknowledged by waldeland who writes that "it centers around a fantastic metamorphosis of an object."isg Henrietta Harmsel adds that "one hardly knows whether the radio. . represents a surrealistic nightmare or 'the real thing." "i>0 This feeling of ambiguity is, according to Tzvetan Todorov, the essential characteristic of the fantastic as a genre:

$159 \mathrm{Waldel}$ and 30

$170^{\circ}$ Henrietta T. Harmsel, "Young Goodman Brown' and 'The Enormous Radio," "studies in Short Fiction 9 (1972): 408 . 
in a world that is indeed our own... there occurs an event which cannot be explained by the laws of this same familiar world. The person who experiences the event must opt for two possible solutions: either he is a victim of an illusion. . . or else the event has indeed taken place, it is an integral part of reality-but then this reality is controlled by laws unknown to us. . . The fantastic occupies the duration of this uncertainty. $1>1$

The ambiguity of signs casts a doubt on the nature of the world in which the characters live. It introduces in this world rules of which the characters are not aware.

In "The Enormous Radio," a New York couple, Jim and Irene Westcott, discovers hidden aspects of the lives of the other residents of their apartment buildings, by listening to their conversations inexplicably captured by a brand new radio. The couple is defined by an accumulation of statistics that can be interpreted as numerical signs of normality:

they were the parents of two young children, they had been married nine years, they lived on the twelfth floor of an apartment house near sutton Place, they went to the theatre on an average of 10.3 times a year. 12

Their only oddity is "the interest they shared in serious music."1>3 This interest is the cause of the intrusion in their lives of the "enormous radio," and with it of a new vision of the world. This radio bears the mark of the preternatural: the green liglit that illuminates the inside

171Tzvetan Todorov, The Fantastic (Ithaca: Cornell University press: 1973) 25 .

172 Cheever 37 .

$1>3$ Cheever 37. 
of the radio is qualified as "malevolent."174 The hint of the "violent forces that were snared in the ugly gumwood cabinet" is one of aggression: "the noise of music [was] amplified so mightily that it knocked a china ornament from a table to the floor."175

The radio serves a disturbing purpose in this world. It not only destroys, but also reveals. symptomatically, its first effect has to do with the most commonly used semiotic system, language. The first significant message heard by Irene is Edward Lear's text "on the coast of Coromandel where the early pumpkins blow. . " told by a nanny to a child in another apartment ${ }^{170}$ This text is a good example of nonsense, but it is not non-sense. It speaks in a reinvented language, but a language that the listener/reader may understand, provided that he goes under the surface of signs. In a way, this first message shows the way to Irene. She must listen and "read" behind what she hears to reach another level of understanding of her world. The various signs she has to read are all the other pieces of conversation caught through the radio, first involuntarily, then with curiosity, greed and anticipation: "see if you can get those people in $18 \mathrm{C."177}$ The various

$$
\begin{aligned}
& 174 \text { Cheever } 38 . \\
& 175 \text { Cheever } 38 . \\
& 175 \text { Cheever } 41 . \\
& 177 \text { Cheever } 42 .
\end{aligned}
$$


signs compose a surface of language that reveals the hidden Iife of these "ordinary" people, the "skin" of a giant organism, the apartment building, an organism that lives and speaks. This "skin" is made of a multitude of signs that can be identified at once. Whereas the referential system is not complete, since she hears only bits of conversation without any context, Irene knows always exactly who is talking. She can therefore discover the most secret aspects of others' lives. Here, the language appears as the tool that can help us either expose or hide what we really have to say.

But the story is not so much about talking as it is about listening. Fate, or God, or some unknown power, has mischievously given Jim and Irene the possibility of discovering the others' reality. Yet, it is ultimately a process of self revelation which Irene undergoes. She realizes that she is not different from those she can hear on the radio, and that she is not outside their semiotic system. Going through the linguistic interface and reaching the other side of signs, she becomes part of this radiophonic theater. She becomes a sign, since her true story is abruptly revealed to the reader: "you packed your bag and went off to have this child murdered as if you were going to Nassau."I>B signs have fulfilled their corrosive function by revealing the true nature of the inner life, the 
life centerea not so much on what one says as on what one keeps for oneself. The forces that brought the signs to Irene and Jim have achieved an ethical revelation that affirms God's omniscience.

"The Enormous Radio" may well be read in conjunction with "O city of Broken Dreams" and in opposition to "A Vision of the world." It implies that there is still a dimension of human freedom available: either refuse to read signs, or accept them entirely. Irene has been tempted, but it is her curiosity which is punished. Even when the characters accept that they should not have confronted the signs, it is already too late. Signs are above all predetermined: their existence implies that men cannot define their own system of meaning and values. If they decide to play the game, men have to accept the rules forced upon them, even if they do not make any sense. What happens when they try to change the rules in the middle of the game? "The swimmer" helps us to find an answer to this question.

The only cheever story ever turned into a movie, ${ }^{79}$ "The swimmer" is also the most commented upon by critics. Michael Byrne sees it as one Cheever's "short masterworks" in which a cross section of America is provided through a "Iist of names."180 Nora Calhoun Graves studies the code of

1.79The Swimmer, dir. Frank Perry, Paramount, 1968. $180 \mathrm{Michael}$ D. Byrne, "The River of Names in 'The Swimmer," "Studies in short Fiction 23 (1986): 327. 
colors that translates the llero's state of mind. ${ }^{181}$ susan Cheever writes that it is a "story in which traditional realism is thoroughly transcended ${ }^{3 z}$ and slabey, who sees in the story the suburbanites' desire to return to an unscathed environment, adds that "The swimmer" is "an imaginative vision of American reality in its interplay of person and object."183

The story tells of a man, Neddy Merrill, who spends his sunday swimming home up a river and from one friend's swimming pool to another. As soon as the story begins, Cheever gives us the essential piece of information we need in order to understand the uselessness of Merrill's journey. He is doomed from the beginning by the sheer effect of time: "he might have been compared to a summer's day, particularly the late hours of one."1m4 Yet, it is a fact of which Merrill himself is not aware ("his life was not confining and the delight he took in his observation could not be explained by its suggestion of escape"). ${ }^{185}$ Merrill perceives himself as a free man, a "legendary figure,"1вs a man who can give names to things like a "cartographer."187

181Nora Calhoun Graves, "The symptomatic Colors in John cheever's 'The swimmer,'" in Critical Essays 191-3.

18zusan Cheever 138 .

${ }^{13}$ Slabey 187 .

xa4Cheever 713 .

3.5 Cheever 714 .

186Cheever 714 .

Is7 Cheever 714 . 
He defines himself as the master of the system of signs in which he lives.

His journey is perfectly planned, always in terms of names, not strictly in terms of places. This plan corresponds to the mental image Neddy has of his "destiny."1вa In other words, Neddy translates his life and his progress (since he calls himself a "pilgrim") 189 into his own system of signs. This is his first contradiction, since the concept of destiny is incompatible with that of human freedom. Moreover, Neddy voluntarily corrupts a religious system of signs. Hal Blythe and charley sweet note the alteration of a system of religious connotations in "The swimmer." They show that the story begins with "a suburban parody of the communal Eucharist" and that Merrill also perverts the "holy sacrament of baptism," and violates the Catholic ritual of marriage. ${ }^{190}$ Neddy operates as a destroyer and negator of Christian figures and symbols. He perverts a divine order and a divine semiotic system. For once, the metaphysical world warns Neddy of his mistake ("private property") 191 and even repeats the warning through a storm. Nevertheless, Merill continues his journey.

28Cheever 715 .

${ }^{189}$ Cheever 715 .

$19{ }^{\circ} \mathrm{Hal}$ Blythe and Charley sweet, "Perverted sacraments in John cheever's 'The Swimmer," studies in short Fiction 21 $(1984): 393-4$. 
After these warnings, the numerous signs that constitute Merrill's environment undergo a rapid process of decay. Merrill understands that something is wrong in the confusion of figures and noises: "then there was an explosion, a smell of cordite, and rain lashed the Japanese lanterns that Mrs. Levy had bought in kyoto the year before, or was it the year before."19z He is still able to address the question of the reason of these changes ("what was the meaning of this excitement"), 193 but time seems to accelerate, and it is the very possibility of free movement that is put in question when Merrill discovers that he cannot go through any waterway: "this breach in the chains of water disappointed him absurdly. . . . He was disappointed and mystified."194 He has to go on foot, which transforms his journey into a trial of humility. Moreover, he has to face the rules that he has been desperately trying to ignore so far. ${ }^{195}$ Yet, he decides once more to ignore them, and refuses to acknowledge the system of signs ("murk") 196 that is reserved to other men.

His denials of the world make time go even faster, so fast, indeed, that he has no time to notice or remember the

$$
\begin{aligned}
& 192 \text { Cheever } 717 . \\
& 193 \text { Cheever } 717 \text {. } \\
& 194 \text { Cheever } 717 . \\
& 195 \text { Cheever } 719 . \\
& 196 \text { Cheever } 719 .
\end{aligned}
$$


changes around him and in himself. He does not recognize the world around him anymore. Even worse, he loses any capability of defining his position, even momentarily. Literally, he loses his star ("what had become of the constellation of midsummer?"). ${ }^{197}$ Ultimately, he reaches what he believes is his house, to find it empty, decayed, and locked. His expression of freedom has turned into a nightmare and the destruction of everything that was his life previously.

Here, signs appear as the guarantors of a divine order. Questioning them is not only difficult, it is also dangerous. Trying to redefine signs and the conditions of their usage is a perversion of the organization of time and space, which make life and knowledge possible. In "The Swimmer," the system of signs affects the reader of the story in a direct manner. As waldeland puts it,

the abruptness of the ending leaves us haunted by this story. Whatever "happened," we have seen a brightly itt, intelligible world suddenly become dark and cold. The story, like a nightmare, leaves the reader with a residual uneasiness. ${ }^{198}$

It is a story in which the distortion of the system of signs affects both the main character and the reader's perceptions. Waldeland makes similar comments upon "Torch Song":

Joan's symbolic dressing in black, our gradual realization that all men are dead, and her mysterious

197 Cheever 724 .

198 Waldeland 95. 
appearance in Jack's life at the moment when he is most vulnerable, all give the story a sort of horror that makes it relatively easy to believe that we have read a story about the Angel of Deathis9

and about "The Geometry of Love":

at first the story seem humorous and Mallory a mild eccentric; only gradually do we realize that the power of geometry is taking over, much as radios and piano exercises in other cheever stories of this kind. ${ }^{200}$

These examples show that when we read Cheever's stories about characters trapped or defeated by signs, the same thing that happens to them happens to us. The pressure exercised by God or Fate on the characters is the same as that exercised by cheever on his reader. The reader is compelled to assume that each story has a meaning, and to determine this meaning.

What does the reader have to do in order to define this meaning? According to Derrida, he must erase the signs and let "difference" operate. Further developing this idea, Barthes explains that "difference must not be perceived as conflict between the writer and the reader. Difference is "achieved beyond and alongside conflict."zos The reader, "the 'I' that approaches the text" and which is "a plurality of other texts, of codes which are infinite,"zoz must operate by erasing previous reading experiences. The text

${ }^{199}$ Waldeland 31.

200 WaIdeland 125 .

${ }^{21}$ Roland Barthes, The Pleasure of the Text (New York:

Hill and Wang, 1975) 15.

202Barthes, s/z 10 . 
read must be constantly recreated so as to "name" and "rename" each meaning. zos Each name cf meaning must be forgotten in order for the reader to carry out the task of reading:

forgetting meanings is not. . an unfortunate defect in performance; it is an affirmative value, a way of asserting. . . the pluralism of systems: it is precisely because I forget that I read. 204

Reacing appears here as a matter of choice on the part of the reader. He may decide to accept the text as it is or rename it ac libitum. He can oppose his "readerly" prerogative as a creative reacer, as a reader who can rename meanings, to the "writeriy," according to Barthes the quality of "what can be written."205

If one accepts these premises, the text and the act of writing appear as compromises between the writer and the reader. The story is defined as a sign because the author agrees to provide the reader with 3 siguified and bealise the reacier accepts to look for the signified he assumes is there. The text as a sign is defined by Barthes as a "contract."

Narrative: legal tender subject to contract, economic stakes, in shout, merchandise, barter which, as here, can be turned into haggling, no longer restricted to the publisher's office nut represented, en abyme, in the narrative. . . . This is the question raised, perhaps, by every narrative. 20 e

\footnotetext{
zo.3Earthes, $\underline{S / Z} 11$.

204 barthes, $\mathrm{S} / \mathrm{Z} 11$.

zosBarthes, $\mathrm{S} / \mathrm{Z} 4$.

zosBarthes, S/Z 89.
} 
But this contract between the writer and the reader is not a fair one. We have already seen how Cheever's characters are trapped and fooled by signs. Cheever's signs to his reader operate in a similar manner. This idea is illustrated in two other short stories: "Three stories" and "A Miscellany of Characters That will not Appear."

In "Three stories," Cheever puts together narrative units that have apparently nothing in common. The "story" is in fact composed of three different narratives that have apparently no connections. Each sub-story is independent in style, tone, technique and point of view. Here, Cheever provides his reader with a system of stories that apparently make absolutely no sense at all. The first element in this triangular system is the discourse of a belly on the "metaphysics of obesity."zor This discourse is not simply a soliloquy: it is intended as a lecture ("The subject today . . " . ${ }^{208}$ The text is not only supposed to exist on its own, but also to be "received" and understood. This part of "Three stories" is didactic: the belly-narrator has to teach us something about human life. Its story is actually the story of the life of an anonymous character, to whom the belly 'belongs.' Life is in a way hidden in the speech of a thing that represents (i.e., speaks for) mankind. However, this discourse is not human. On the contrary, human

\footnotetext{
207 Cheever 793. 208 Cheever 793 .
} 
activities seem to be focused on silencing the belly: "he stubbornly refused to grant me my rights and continued for almost a year to wear clothes that confined me harshly and caused me much soreness and pain."zos

The beliy has a voice of its own. It is part of a greater organic structure. Yet, its existence becomes separate from that of the human body as a whole. The voice (the linguistic existence) of an object, albeit a human object, appears in this story to be separate from the object itself. However, at the end of the story, there is a fusion of both elements, the acceptance on the part of the body of the separateness of one of its constitutive elements: "I knew that I had won and that we had arrived at a sensible truce."210 This fusion is triggered by a long trip of the "character," expressed by Cheever through the accumulation of twenty-six exotic names of countries and islands. The proper names are used here by the "belly" because of the arbitrariness and univocity of their Iinguistic function: one place is supposed to correspond to one name. In the same way, the belly is associated to one body. This compromise is also one of silence, since the fusion marks the end of the story. The first third of the "Three stories" seems to imply that the reunion of the two sides of

\footnotetext{
${ }^{209}$ Cheever 794-5. 210 Cheever 797 .
} 
an entity, its voice and its nature, is possible, but also triggers the end of its individual discourse.

Compared to this first sub-story, the second one appears as a complete non sequitur. It is the story of a typical American, Marge Littleton, told by a first-person narrator. The woman is the epitome of the American suburban wife, whose life is organized into a comfortable routine. suddenly, Marge's life is turned into horror: twice, within a few years, she loses husbands and family in traffic accidents which occur on the same road. The rest of the action is not centered on Marge's life, but on the particular segment of road where accidents continue to occur. Ultimately, the police discover that the last few accidents were in fact murders and that a sniper is stalking truck drivers. The last paragraph of the story tells of Marge's next marriage and of her leaving the area of Road 54. Yet, nothing explicitly links Marge and the killings. Cheever seems to imply that Marge is somehow responsible for the shootings, to avenge the deaths of her two husbands. otherwise, the text becomes a series of episodes in which the only common point is that they all took place near one particular spot. The link between the several episodes is created in the reader's mind to suggest an internal coherence. In order to make the story mean something, the reader has to reassociate, arbitrarily, the two facets of a semantic system in which the signified is only suggested: the text as a detective story. 
But how is this process initiated? At the beginning of the story, Cheever weaves a network of connotations implying that, although Marge appears to be the typical American woman, there is something odd about her: "Marge ititleton would, in the long gone days of Ereudian jargon, have been thoughi maternal, although she was no more maternal than you or you."211 cheever places this "would-be" analysis of her character on the level of language. The analysis is possible and, although it is not necessary to the establishment of Marge's character, it is a least a way of explaining a possible murderous behavior. once again. the end of the second sub-story is marked by the arbitrary fusion of two faces of a seniotic system.

Is this pattern discernible in the third sub-story? This story tells of a chance encounter betweer an anonymous man and an anonymous woman ir an airplane. Inmediately, cheever emphasizes the way in which the two characters communicate or pather do not: "Good evening," he said, settling Mimself. She dian't reply."ux Here the reader is confronted by all the possible elements of a love story. Yet Cheever again exercises a strong constraint upon his characters and his readers. The love story does not work, and does not even start. Signs here become silent, in the same wy that the sncking-sign in the plane is turned

\footnotetext{
:19heever 797 .

21 cheever 801.
} 
off.213 But this silence of signs is not an absence of signs. It is a sign in itself, since, as Handelman puts it, "absence does not equal nonexistence." ${ }^{4}$ the text goes on in spite of the lack of communication between the characters. The text follows a necessary movement which is expressed in the text, by an analogy, the description of the movie that is shown on the flight: "the characters on the screen relentlessly pursued their script. There was a parade, a chase, a reconciliation, an ending."215

The third sub-story has an ending. It comes abruptly, after a series of questions: "He is her husband, she is his wife, the mother of his children and a woman he has worshipped passionately for nearly thirty years".215 The questions listed all begin with "why." Their purpose is to show that, to account for the series of signs provided by the text, one has to formulate a punchline. The three stories, although totally different in style, genre, narrative technique and tone, converge the same point. However different and senseless the basic elements might appear, it is always possible for the writer to assign a meaning to the stories he writes. This meaning is independent of the reader's intention. In fact, the reader is forced into the

$$
\begin{aligned}
& 213 \text { Cheever } 801 . \\
& 214 \text { Handelman } 172 . \\
& \text { 215Cheever } 803 . \\
& 215 \text { Cheever } 804 .
\end{aligned}
$$


acceptance of a significant network of signs. The ultimate proof of this narrative method is the coagulation of one short story out of three heterogeneous parts. "Three stories" is a three-fold sign, but a sign nonetheless. Its meaning is that, however chaotic their birth might appear to the reader, this reader may construct a meaning. There is no contract here between cheever and his reader: it is the reader who makes the text readable. In the same way that cheever's characters reach a type of closure by convincing themselves they do so, Cheever's reader may reach a certain moral closure by thinking he does so.

"A Miscellany of Characters that Will Not Appear" operates in a similar manner. The method used by Cheever, however, is different: he makes his point in a negative manner, by tearing a story into pieces, by deconstructing it. The story, which is not really a story but simply an accumulation of notes, of seven passages, dealing with possible characters, themes, or plot, proceeds from a paradox: by writing about the characters, cheever makes them appear, in spite of the title. Therefore, something in the story informs the reader why the characters do not real1y appear. The raw material of the story is a series of flashes and episodes. The characters of these episodes may have names ("Elorrie" in a rugby scene) and may be anonymous ("X" in the fifth passage). There may be no character at all, simply a general background in which any character may be placed by the writer: "they are. . . the temporary 
encampments and outposts of the civilization that we--you and I--shall build."217 The characters may be involved in an action, as with " $\mathrm{X}$ " in the fifth passage, or may be narratively inert. These actions seem to be totally senseiess, as if they are not part of a logical sequence. Fach passage has the potential for an individual story. It represents the conditions of a narrative, its raw material. It defines the semiotic background of a series of stories, without providing the stories themselves. What cheever offers his reader is the general framework of narrative production. Cheever is like a chess master showing the basics of the game to a new player. He shows, for instarce, the opening moves: "All such scenes as the following: "Clarissa stepped into the rooom and then --"ar He also shows possible variations and endgames, but he is actually not conducting a play. He provides us with the general information necessary to the creation of a story, but does not initiate a particular organization of the story. He does not suggest any direction in which the signs should be organized.

Yet, the signs are organized noretheless.

Paradoxically, all the elements necessary to the spontaneous creation of such a direction are present in the text: the opening, the ending, the background, the characters, the

217 Cheever 552 .

$21{ }^{8}$ Cheever 552 . 
names, the plot, the action, even the possibility of a movie adaptation. They even entertain intertextual relationships, for instance when the name of Brando, mentioned in the second passage, is echoed in the seventh. 219 "A Miscellany of Characters that will not Appear" functions as if these clusters of signs do not generate a global sign as they do in the "Three stories."

What is missing, then, in order to generate a story? For once, Cheever provides his reader with an explicit answer, that is, an answer making explicit the role of the storyteller by making him a character of a passage. He does so by inserting himself in the text and telling us that he has no time to write a story ("I have to go to the dentist and then have my hair cut"). 220 Cheever seems to suggest that the organization of the signs into a significant structures depends entirely on the writer's intention. William peden actually describes the story as a "moving manifesto and declaration of intention."zzi But a declaration is not a performance. Corroborating this point. the story is characterized by the presence of an unsuccessful writer. This writer, Royden Blake, is no longer able to create anything but enumerations of characters: "you might say that he had lost the gift of

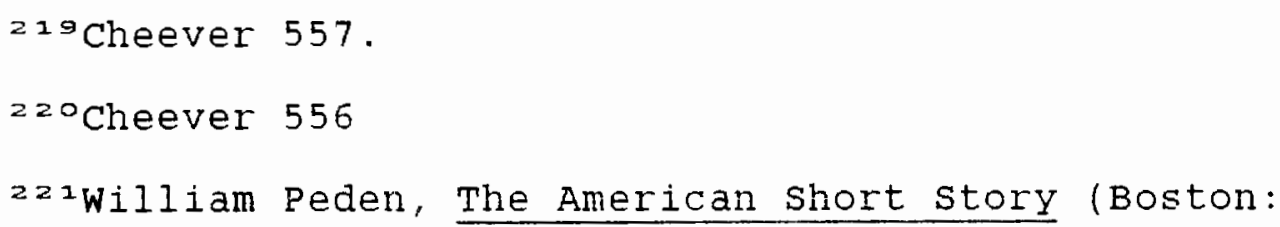


evoking the perfumes of life." 222 He is not able to make a coherent vision of the world into a story. He has lost contact with the world of literary creation, the world in which things have names and fit into a general and ordained structure.

In a world of exploded signs, there is no reliable meaning for Blake to rely on: "how could this snowy and trumped-up pass, with its trio of travelers, hope to celebrate a world that lies spread out like a bewildering and stupendous dream?" 223 In "The Geometry of Love, "the main character dies of an hyperpresence of signs, whereas Blake dies of their hyperabsence. Both deaths are the affirmation of cheever's omnipotence as a storyteller. It is cheever who decides to fill the world with signs destined to the characters. The characters may or may not read them. They may or may not understand them. They may or may not accept them. But they are always affected by them. And in the same way, even if the reader sometimes creates something with the signs he is given by the effect of the readerly powers, he ultimately acknowiedges the power of the witeriy. The reader comes to the realization that

signs are no proof, since anyone can produce false on ambiguous signs. Hence one falls back, paradoxically, on the omnipotence of language: since nothing assures language, I wil regard it as the sole and final assurance: I shall no longer believe in interpretation. 224

222 cheever 557 .

223 Cheever 558 .

224Barthes, Lover 215. 
In his short stories, Cheever submits his reader to such a process. As John Aldridge puts it, cheever is a writer "who prefers to give comfort rather than to educate and transform consciousness."225 when he does not destroy his character, Cheever always returns to a certain closure, the "reassuring" (but not comfortable) certitude of before the crisis. As Gerlach points out,

if one looks at the plot, the logical sequence of events, cause leading to effect and thence again to cause. . . the story will be considered meaningless. But if one attends to the closural aspects of figurative elements, of formal pattern, and of the author's skill and wit in turning these to accounts, the story will satisfy. 220

This is what cheever does when he provides signs to his reader: after having allowed his reader to look for a meaning, he finally leads him to a closure of the semiotic system and to the refusal of their interpretation.

$225 \mathrm{John}$ W. Aldridge, Time to Murder and Create (New York: Books for Library Press, 1966) 176. 
CONCLUSION

There is relatively little criticism dealing with

Cheever's short stories. Although written twenty years ago: Aldridge's evaluation is still true today:

if you have searched as I have for critical discussion of John cheever that goes beyond the mere reviews and treats of his special gifts with some real thoroughness and force, you will probably already share my conviction that cheever is one of the most grievously underdiscussed important writers we have at the present time. 227

The purpose of this thesis has been to propose a new approach to Cheever's stories. Its main point is that the issue of signs is important to the understanding of cheever's short fiction. The characters in the stories studied are looking for a definition of their space in American society. In other words, they are looking for an affirmation of their place in a semiotic system. Their world, colonized by signs, has become meaningless. They try to redefine an order by redefining the rules of reading the signs that surround them. But either they are unprepared to decipher the world in a Rabbinic or Derridean manner, or they cannot cope with the consequences of their reinterpretation. There are only two ways to escape the trap of signs: either the characters must disappear, or they 
have to return to the system of signs that created their ennui.

In the same way, the reader of the short story is confronted by a multitude of signs that he has to interpret over and over again. Vet, ultimately, the decision to make sense of the story is not up to him, but to the author. Cheever is constantly lying to his reader when he briefly allows him to read the ambiguity of signs and the plurality of their signified in his short stories. In his interview with Grant, Cheever admits:

for one thing, the words "truth" and "reality" have no meaning at all unless they are fixed in a comprehensible frame of reference. There are no stubborn truths. As for lying, it seems to me that falsehood is a critical element in fiction. 228

Cheever's purpose is not, therefore, to illustrate reality, but to use signs as catalysts for the reader to reevaluate the givens of his world. In another interview, Cheever says: "the force of reality in fiction and the force of reality in a dream are very much the same... . The experience of fiction is similar [to the nature of dreams]: one builds it as if at random" (my emphasis). 229 But this appearance of dream has to be erased sooner or later. Like the narrator of "A Vision of the world," we have to leave

228 John Cheever, interview with Annette Grant, in Critical Essays 88 . Essays 105 .

zagJohn Cheever, interview with John Hersey, in Critical 
sooner or later the world of the "freeplay" of meaning. The force of the writer is ultimately asserted.

To regain a unity, cheever's ultimate certainty is that of God's existence. And if cheever likes to appear as the mischievous god of his own short stories, it is perhaps only to preserve the hypothesis of a loving God, creator and guarantor of all signs in the real world. The "literary predetermination" of cheever's world, the fact that the characters must accept signs for what they are and must reconstruct the world they have tried to deconstruct, all is the acknowledgement of God's almightiness. In his struggle against alcoholism and homosexuality recalled by his daughter, Cheever's faith never faltered. As Joshua Gilder puts it:

throughout his life, cheever has tried to bring order to chaos and to exalt the decent and beautiful, though he often doubted that good would prevail over evil. The despair in his fiction is palpable. But so too is the abiding faith that answers it.230

Finaliy, must one consider cheever an oddity in the development of modern American short fiction, or is there a lirk between Cheever and other contemporary American writers? Most critics are quite elliptical about this point. Peden, who places Cheever among writers such as Hortense Calisher, John O'Hara, Peter Taylor, and John Jpdike, whom he defines as "Jane Austens of Suburbia,"zaz

$$
\begin{aligned}
& \text { 230 Gilder } 19 . \\
& \text { 231Peden } 45 .
\end{aligned}
$$


only says that "the vague, undefinable sadness of John Cheever's "The season of Divorce" might serve as emblem for many recent American short stories."z3z Aldridge writes that cheever

does not yet disturb us enough. He does not yet rouse enough fear. And until he does, he seems destined to remain a writer best known and most admired by all the wrong people for his discomforting limitations. ${ }^{23}$

Fifteen years after the publication of his last book of short stories, and seven years after his death, perhaps Cheever's influence is perceptible on the short fiction writers who affirm the corrosiveness of the plethora of signs in American society. Yet, the only hint of such an influence is found in Raymond Carver's "The Train," dedicated to cheever ${ }^{234}$ and the sequel to one of his darkest stories, "The Five-Forty-Eight." In his analysis of the connections between the two stories, Mark Facknitz writes:

"The Train" illustrates the estrangements we suffer because we assume that the inner lives of others have come to resemble the suburb of pointless order from which they issue. ${ }^{235}$

Crisis, signs of identity, necessity to be part of a social ond semiotic system--we have here all the elements studied in this thesis.

$$
\begin{aligned}
& 232 \text { peden } 42 . \\
& 233 \text { Aldridge } 177 . \\
& \quad 234 \text { Raymond Carver, "The Train," in The Stories of } \\
& \text { Raymond Carver (London: Pan Books, 1985) } 390 . \\
& \quad 235 \text { Mark A. Facknitz, "Missing the Train: Raymond }
\end{aligned}
$$
Carver's Sequel to John Cheever's 'The Five Forty Eight, " Studies in short Fiction 22 (1985): 347 . 


\section{WORKS CONSULTED}

on structuralism and Deconstruction:

Barthes, Roland. Elements of Semiology. Trans. Annette Lavers and colin Smith. New York: Hill and Wang, 1968 .

---. Writing Degree Zero. Trans. Annette Lavers and Colin smith. New York: Hill and wang, 1968.

--. The Pleasure of the Text. Trans Richard Miller. New York: Hill and Wang, 1975.

-.. S/Z. Trans. R. Miller. New York: Hill and Wang, $1 \overline{977}$.

--. A Lover's Discourse, Fragments. Trans. Richard Miller. New York: Hill and Wang, 1978.

Berg, Temma. "La carte postale: Reading (Derrida) Reading." criticism 28 (1986): 323-40.

Berger, Arthur A. Signs in Contemporary Culture. New york: Longman, 1984 .

Bloom, Harold. Deconstruction and Criticism. New York: The seabury press, 1979.

Culler, Jonathan. "Jacques Derrida," in Structuralism and Deconstruction from Levi-strauss to Derrida, ed. J. starrock. Oxford: Oxford University Press, 1979.

---. The Pursuit of Signs: Semiotics and Literature. New york: Cornell university press, 1981.

---. On Deconstruction: Theory and Criticism after structuralism. London: Routledge and Kegan Paul, 1983 .

Deleuze, Gilles. Marcel proust et les signes. Paris: Presses Universitaires de France, 1964.

Derrida, Jacques. of Grammatology. Trans. G. C. Spivak. Baltimore: Johns Hopkins University Press, 1974. 
--. "structure, sign and Play in the Discourse of the Human Sciences," in The Language of Criticism and the Sciences of Man, eds. Richard Macksey and Eugenio Donato. Baltimore: Johns Hopkins Press, 1970.

--- Writing and Difference. Trans. Alan Bass. Chicago: The University of Chicago Press, 1978.

-.-. "Différance," in Critical Theory since 1965, eds. Hazard Adams and Leroy Searle. Tallahassee: Florida state university press, 1986.

-- . The Postcard. Trans. Alan Bass. Chicago: University of Chicago Press, 1987.

Ducrot, oswald. "Le structuralisme en Linguistique." In qu'est-ce que le structuralisme. Paris: Seuil, 1968.

Ducrot, oswald, and Tzvetan Todorov, eds. Dictionnaire Encyclopédique des sciences du Langage. Paris: Seuil, 1972 .

Felperin, Howard. Beyond Deconstruction: The Uses and Abuses of Literary Theory. Oxford: oxford University Press, 1985 .

Fischer, Michael. Does Deconstruction Make Any Difference? Indiana University Press, 1985.

Gasché, Rodolphe. The Tain of the Mirror. Cambridge: Harvard University Press, 1986.

Greimas, Julien Algirdas, and Courtès, Joseph. Sémiotique: Dictionnaire Raisonné de la Théorie du Langliage. Paris: Hachette, 1970.

Handelman, Susan. The Slayers of Moses: The Emergence of Rabbinic Interpretation in Modern Literary Tradition. Albany: state University of New York Press, 1982.

Hartman, Geoffrey. Saving the Text: Literature/Derrida/ philosophy. Baltimore: Johns Hopkins University Press, 1981 .

Harvey, Irene E. Derrida and the Economy of Differance. Bloomington: Irdiana University Press, 1986.

Jefferson, Ann, and Rubey, D. "structuralism and PostStructuralism," in Modern Literary Theory: A Comparative Introduction, eds. A. Jefferson and $D$. Rubey. London: Batsford, 1982. 
Kofman, sarah. Lectures de Derrida. Paris: Galilée, 1984.

Kurzweil, Edith. The Age of Structuralism. New-York: Columbia University Press, 1980.

Lacan, Jacques. "Le Séminaire sur 'La Lettre Volée." In Ecrits I. Paris: Seuil, 1971.

Leitch, vincent. Deconstructive Criticism. New York: Columbia University Press, 1980.

Lentricchia, Frank. After the New Criticism. London: Athlone Press, 1980.

Merrell, Floyd. Deconstruction Reframed. Indiana: Purdue University press, 1385.

Melville, stephen. Philosophy Beside Itself: on Deconstruction and Modernism. Minneapolis: University of Minnesota Press, 1986.

Porter, James. "Saussure and Derrida on the Figure of the Voice," MLN 101 (1986): 871-94.

Ray, William. Literary Meanings, from Phenomenology to Deconstruction. Oxford: Basil Blackwell, 1984.

Rey-Debove, Josette. Lexique Sémiotique. Paris: Presses Universitaires de France, 1979.

De Saussure, Ferdinand. Cours de Linguistique Générale. Paris: Payot, 1978.

Simon, John K., ed. Modern French Criticism. Chicago: University of cinicago Press, 1972.

Todorov, Tzvetan. The Fantastic: A structural Approach To A Literary Genre. Ithaca: Cornell University Press, 1980 .

on John Cheever:

Aldridge, John $w$. Time to Murder and create. Freeport: Books for Libraries Press, 1966.

Blythe, Hal, and Charlie sweet. "Perverted Sacraments in John Cheever's 'The Swimmer.'" Studies in Short Eiction 21 (1984): $393-4$.

Byrne, Michael D. "The River of Names in 'The Swimmer." studies in short fiction 23 (2986): 326-7. 
Cheever, Joln. "hhy I write short stories." Newsweek 30 oct. 1978: 24-5.

--- The short Stories of John cheever. New York: Ballantine, 1980 .

Cheever, Susan. Home Before Dark. Boston: Houghton Mifflin, $198 \overline{4}$.

Collins, Robert $G$. "From Subject to object and Back Again: Individual Identity in John Cheever's Fiction."

Twentieth century Iiterature 28 (1982): 1-13.

-- ed. Critical Essays on John Cheever. Boston: $G$. K. $\mathrm{Hal1}, 1982$.

Facknitz, Mark A. R. "Missing the Train: Raymond Carver's sequel to John Cheever's "The Five-Forty-Eight. '" studies in short Fiction 22 (1985): 345-7.

Geriach, John. "Closure in Modern short Fiction: cheever's 'The Enormous Radio' and 'Artemis, the Honest well Digger." Modern Fiction Studies 28 (1982): 145-52.

Gilder, Joshua. "John cheever's Affirmation of Faith." Saturday Review March 1982: 16-19.

Gussow, Adam. "Cheever's Failed Paradise: The short-story styiist as Novelist." Literary Review 27 (1983): 103$1 \epsilon$.

Harmsel, Henrietta T. "Young Goodman Brown' and 'The Enormols Radio." Studies in Short Fiction 9 (1972): 407-408.

Kendel, Burton. "Cheever's Jse of Mythology in 'The Enormous Radio." "studies in Short Fiction 4 (1967): $262-64$.

Peden, William. The American Short Story. Boston: Houghton Miffin, $196 \overline{4}$.

scully, James. "An Oracle of Subocracy." Rev. of The Brigadier and the Golf widow, by John Cheever. The Nation 8 Feb. 1965: 144-5

Stengel, Wayne. "John Cheever's surreal Vision and the Bridge of Language." Twentieth Century Literature 33 $(1987): 223-33$.

Voss, Arthur. The American short story, A Critical survey. Norman: University of oklahoma Press, 1973. 
Waldeland, Iynne. John Cheever. Boston: Twayne, 1979.

warnke, Frank J. "Cheever's Inferno." Rev. of Some People, Places, and Things That will Not Appear in my Next Novel, by John Cheever. The New Republic 18 May 1961: 15 .

Weaver, John, ed. The American Short story 1945-1980.

Boston: Twayne, 1983. 